\title{
The IRP/IRE system in vivo: insights from mouse models
}

\section{Nicole Wilkinson and Kostas Pantopoulos*}

Lady Davis Institute for Medical Research, Jewish General Hospital, and Department of Medicine, McGill University, Montreal, QC, Canada

\section{Edited by:}

Paolo Arosio, University of Brescia Italy

\section{Reviewed by:}

Mayka Sanchez, Josep Carreras

Leukaemia Research Institute (IJC),

Spain

Carole Beaumont, INSERM, France

*Correspondence:

Kostas Pantopoulos, Lady Davis Institute for Medical Research,

Jewish General Hospital, and

Department of Medicine, 3755 Cote

Ste-Catherine Rd., Montreal, OC

H3T 1E2, Canada

e-mail:kostas.pantopoulos@

mcgill.ca
Iron regulatory proteins 1 and 2 (IRP1 and IRP2) post-transcriptionally control the expression of several mRNAs encoding proteins of iron, oxygen and energy metabolism. The mechanism involves their binding to iron responsive elements (IREs) in the untranslated regions of target mRNAs, thereby controlling mRNA translation or stability. Whereas IRP2 functions solely as an RNA-binding protein, IRP1 operates as either an RNA-binding protein or a cytosolic aconitase. Early experiments in cultured cells established a crucial role of IRPs in regulation of cellular iron metabolism. More recently, studies in mouse models with global or localized Irp1 and/or Irp2 deficiencies uncovered new physiological functions of IRPs in the context of systemic iron homeostasis. Thus, IRP1 emerged as a key regulator of erythropoiesis and iron absorption by controlling hypoxia inducible factor $2 \alpha$ (HIF2 $\alpha$ ) mRNA translation, while IRP2 appears to dominate the control of iron uptake and heme biosynthesis in erythroid progenitor cells by regulating the expression of transferrin receptor 1 (TfR1) and 5-aminolevulinic acid synthase 2 (ALAS2) mRNAs, respectively. Targeted disruption of either Irp1 or Irp2 in mice is associated with distinct phenotypic abnormalities. Thus, Irp1-/- mice develop polycythemia and pulmonary hypertension, while Irp2 $2^{-/}$mice present with microcytic anemia, iron overload in the intestine and the liver, and neurologic defects. Combined disruption of both Irp1 and Irp2 is incombatible with life and leads to early embryonic lethality. Mice with intestinal- or liver-specific disruption of both Irps are viable at birth but die later on due to malabsorption or liver failure, respectively. Adult mice lacking both Irps in the intestine exhibit a profound defect in dietary iron absorption due to a "mucosal block" that is caused by the de-repression of ferritin mRNA translation. Herein, we discuss the physiological function of the IRE/IRP regulatory system.

Keywords: iron metabolism, ferritin, ferroportin, aconitase, transferrin receptor, HIF2 $\alpha$, DMT1, hepcidin

\section{PRINCIPLES OF MAMMALIAN IRON METABOLISM}

Iron is a vital micronutrient and constituent of several metalloproteins (Aisen et al., 2001). Even though it may acquire many oxidation states (from -2 to +6 ), within cells iron commonly alternates between the ferrous $\mathrm{Fe}(\mathrm{II})$ and ferric $\mathrm{Fe}(\mathrm{III})$ forms. Because of its abilities to coordinate with proteins and to act as both an electron donor and an electron acceptor, iron has been utilized throughout evolution by almost all living cells and organisms for metabolic purposes. Thus, iron is an integral component in: oxygen transport, through the heme moiety of hemoglobin; cellular respiration, as part of heme-containing cytochromes and Fe-S cluster-containing proteins of the electron transport chain (ETC); DNA synthesis and cellular growth, as part of the M2 subunit of ribonucleotide reductase.

As essential as iron is to survival, it can also be toxic. "Free" iron engages in Fenton chemistry to catalyze the production of hydroxyl radicals from superoxide and hydrogen peroxide (Papanikolaou and Pantopoulos, 2005). These are extremely reactive species that can damage lipid membranes, proteins and nucleic acids within a cell. To avoid the deleterious effects of the Fenton reaction, iron has to be shielded. Circulating iron is oxidized to $\mathrm{Fe}(\mathrm{III})$ and tightly binds to transferrin
(Tf), which maintains it in a redox-inert state and delivers it to tissues (Gkouvatsos et al., 2012). Cellular iron uptake involves the binding of iron-loaded $\mathrm{Tf}$ to transferrin receptor 1 (TfR1) and the internalization of the complex by endocytosis (Aisen, 2004). Within endosomes, $\mathrm{Fe}(\mathrm{III})$ is released from Tf following acidification, and undergoes reduction to $\mathrm{Fe}(\mathrm{II})$. Subsequently, $\mathrm{Fe}(\mathrm{II})$ crosses the endosomal membrane via the divalent metal transporter 1 (DMT1). Internalized iron is mostly utilized in mitochondria for synthesis of heme and Fe-S clusters, and in the cytosol for incorporation into metalloproteins, while excess of iron is stored and detoxified within ferritin (Arosio et al., 2009). Ferritin is ubiquitously expressed in the cytosol of cells. It is comprised of $24 \mathrm{H}$ - and L-polypeptide subunits that form a shell-like nanocage for iron storage, with a diameter of $7-8 \mathrm{~nm}$. This can accommodate up to 4500 iron atoms, which are safely stored in the form of ferric oxyhydroxide phosphate, following oxidation of $\mathrm{Fe}(\mathrm{II})$ to $\mathrm{Fe}(\mathrm{III})$ at the ferroxidase center of the $\mathrm{H}$-ferritin subunit. In addition, a distinct ferritin isoform (M-ferritin) is expressed in mitochondria of some cell types, such as testicular Leydig cells, neuronal cells and pancreatic islets of Langherans (Levi and Arosio, 2004). 
The iron content of the adult human body ranges between 3 and $5 \mathrm{~g}$ (Gkouvatsos et al., 2012). Most of it ( $70 \%)$ is utilized in hemoglobin of red blood cells (RBCs) in the bloodstream and of erythroid progenitor cells in the bone marrow, and is recycled by tissue macrophages at a rate of $25-30 \mathrm{mg} /$ day (Figure 1). A substantial amount of body iron (up to $1 \mathrm{~g}$ ) is stored within ferritin in the liver. Muscles contain $\sim 300 \mathrm{mg}$ of iron (mostly in myoglobin), and all other tissues (excluding the duodenum) merely $\sim 8 \mathrm{mg}$. Circulating Tf-bound iron represents a small ( $\sim 3 \mathrm{mg}$ ) but dynamic fraction that turns over $\sim 10$ times per day (Cavill, 2002). The Tf iron pool is primarily replenished by iron from senescent RBCs that is recycled via macrophages, and to a smaller extent by iron absorbed from the diet via duodenal enterocytes. In adults, dietary iron absorption (1-2 mg/day) serves to compensate for non-specific iron losses (by desquamation or bleeding).

Iron metabolism is regulated at both the systemic and cellular levels. Systemic iron homeostasis is controlled through hepcidin, a liver-derived peptide hormone (Ganz, 2013). Iron and other stimuli (inflammation, endoplasmic reticulum stress) positively regulate hepcidin transcription, while erythropoietic drive suppresses it. Hepcidin binds to the cellular iron exporter ferroportin expressed on enterocytes, macrophages, and hepatocytes causing ferroportin's subsequent internalization and degradation (Nemeth et al., 2004). Ergo hepcidin functions to control iron absorption within the enterocytes and the efflux of iron into the bloodstream from macrophages and other iron exporting cells (Figure 2). Misregulation of hepcidin is associated with disease (hemochromatosis, when iron-regulation of hepcidin is blunted, and anemia, when hepcidin is induced by

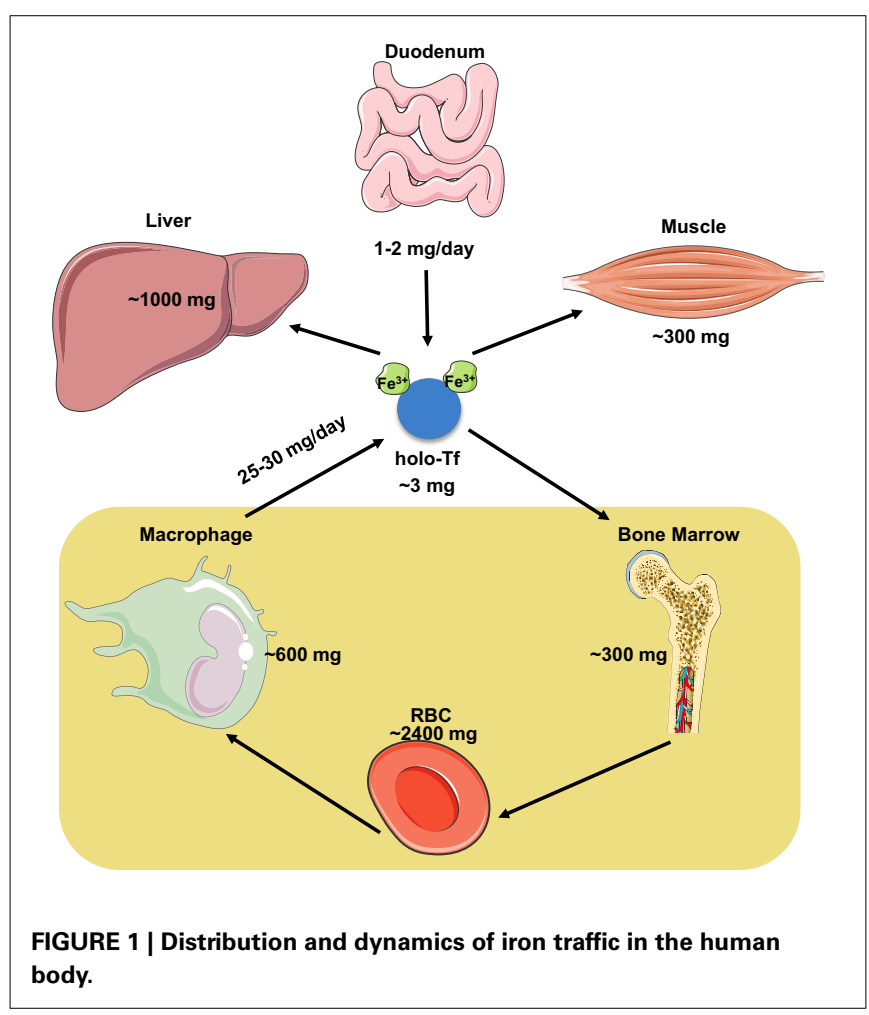

inflammatory pathways or by genetic inactivation of its inhibitor TMPRSS6) (Sebastiani and Pantopoulos, 2011). Cellular iron metabolism is controlled through the IRE/IRP system (Wang and Pantopoulos, 2011; Joshi et al., 2012), which is the focus of this review.

\section{COORDINATE POST-TRANSCRIPTIONAL REGULATION OF CELLULAR IRON METABOLISM VIA IRE/IRP INTERACTIONS}

The IRE/IRP regulatory system was first described in the late 1980s with the discovery of iron responsive elements (IREs) in the untranslated regions (UTRs) of the mRNAs encoding ferritin (both $\mathrm{H}$ - and L-subunits) and TfR1 (Hentze et al., 1987; Casey et al., 1988; Müllner and Kühn, 1988); see Figure 3. IREs are highly conserved hairpin structures of 25-30 nucleotides (Piccinelli and Samuelsson, 2007). They contain a stem that is stabilized by base pairing, and a loop with the sequence $5^{\prime}$ CAGUGH-3' ( $\mathrm{H}$ denotes $\mathrm{A}, \mathrm{C}$ or $\mathrm{U}$ ). The stem is interrupted to an upper and lower part by an unpaired $\mathrm{C}$ residue or an asymmetric UGC/C bulge/loop. H- and L-ferritin mRNAs contain a single IRE in their $5^{\prime}$ UTR, which is located relatively close to the cap structure at the $5^{\prime}$ end. TfR 1 mRNA contains five IREs in its $3^{\prime}$ UTR.

The IREs constitute binding sites of two cytoplasmic iron regulatory proteins, IRP1 and IRP2 (Rouault, 2006). Under conditions of iron deficiency, IRP1 and IRP2 bind with high affinity to the IRE in $\mathrm{H}$ - and L-ferritin mRNAs, and thereby inhibit their translation by a steric hindrance mechanism. Likewise, they bind to the IREs in TfR $1 \mathrm{mRNA}$ and thereby protect it against endonucleolytic degradation. This homeostatic response mediates increased cellular iron uptake from $\mathrm{Tf}$ and prevents storage of the metal. By contrast, in iron-replete cells the IRE-binding activities of IRP1 and IRP2 are diminished, allowing TfR1 mRNA degradation and ferritin mRNA translation. This inhibits further iron uptake and stimulates storage of excessive intracellular iron within ferritin. A scheme with the coordinate post-transcriptional regulation of ferritin and TfR1 by IRE/IRP interactions is shown in Figure 4.

Additional IRE-containing mRNAs (Figure 5) have been discovered by computational and biochemical approaches, as well as high throughput screens (Dandekar and Hentze, 1995; Gunshin et al., 1997; McKie et al., 2000; Sanchez et al., 2006, 2007, 2011). These include the mRNAs encoding the iron transporters DMT1 and ferroportin, the enzyme 5-aminolevulinic acid synthase 2 (ALAS2) that catalyzes the first reaction for heme biosynthesis in erythroid progenitor cells, the enzyme of the citric acid cycle mitochondrial aconitase, the cell cycle regulator CDC14A, and hypoxia inducible factor 2 alpha (HIF2 $\alpha$ ), a transcription factor that orchestrates molecular responses to hypoxia. All these transcripts harbor a single IRE. The IRE of ferroportin, ALAS2, mitochondrial aconitase and HIF $2 \alpha$ mRNAs is localized in the $5^{\prime}$ UTR and functions as a translational control element, analogous to ferritin IRE. The IRE of DMT1 and CDC14A mRNAs is localized in the $3^{\prime}$ UTR and appears to function as an mRNA stability element. Post-transcriptional regulation of DMT1 expression by the IRE/IRP system is cell-specific (Gunshin et al., 2001) and depends, at least partially, on an alternatively transcribed upstream exon at the $5^{\prime}$ end of DMT1 mRNA 

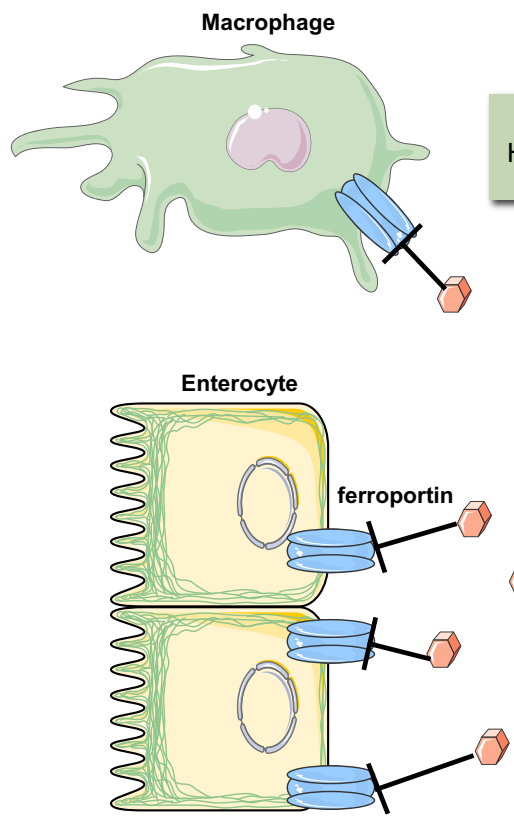

FIGURE 2 | Hormonal regulation of iron efflux from reticuloendothelial macrophages and duodenal enterocytes. The iron regulatory hormone hepcidin is secreted by liver hepatocytes and targets the iron transporter ferroportin on the plasma membrane of iron-exporting cells. The binding of hepcidin promotes ferroportin degradation in lysosomes. Hepcidin expression is induced in response to high iron stores and inflammatory signals. Conversely, hepcidin expression is suppressed in response to iron deficiency and increased erythropoietic drive.

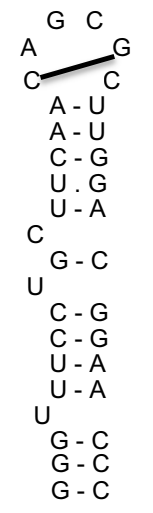

H-Ferritin

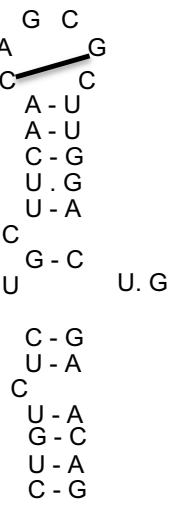

L-Ferritin

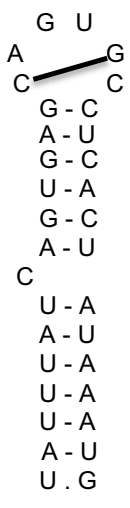

TfR1 (A)
FIGURE 3 | IRE motifs in the untranslated regions of the mRNAs encoding human H-ferritin, L-ferritin and TfR1 (only the A IRE of TfR1 mRNA is shown). Watson-Crick base pairing is depicted by a dash and non-Watson-Crick interactions by a dot. The line connecting the 1 st and 5 th nucleotide of the IRE loop indicates Watson-Crick base pairing.

(Hubert and Hentze, 2002). Notably, earlier experiments showed that the presence of at least three $3^{\prime}$ UTR IREs is essential for iron-dependent regulation of TfR1 mRNA (Casey et al., 1989), which remains the only transcript containing multiple IREs. It should also be noted that DMT1, ferroportin and CDC14A mRNAs include additional non-IRE-containing isoforms, which are generated by alternative splicing and exhibit differential tissue distribution (Hubert and Hentze, 2002; Sanchez et al., 2006; Zhang et al., 2009).

Another level of complexity is added by the fact that iron regulation of HIF2 $\alpha$, ferroportin and DMT1 integrates multiple and often opposing signals (Mastrogiannaki et al., 2013; Shah and Xie, 2014). Thus, while iron stimulates HIF2 $\alpha$ and ferroportin mRNA translation, it also promotes the degradation of HIF $2 \alpha$ via iron- and oxygen-dependent prolyl hydroxylases (PHDs) and the von Hippel Lindau E3 ubiquitin ligase (pVHL) (Schofield and Ratcliffe, 2004), and the degradation of ferroportin via hepcidin (Ganz, 2013). Conversely, iron deficiency inhibits translation of HIF $2 \alpha$ and ferroportin mRNAs but promotes stabilization of the proteins. On the other hand, iron deficiency leads to HIF $2 \alpha$-mediated transcriptional activation of duodenal DMT1 and ferroportin, the apical and basolateral transporters of iron in enterocytes (see below).

\section{SENSING OF INTRACELLULAR IRON BY IRP1 AND IRP2}

IRP1 and IRP2 are homologous to mitochondrial aconitase (Rouault, 2006; Wang and Pantopoulos, 2011). A characteristic feature of this enzyme is the presence of a $4 \mathrm{Fe}-4 \mathrm{~S}$ cluster within its active site, which is indispensable for catalytic isomerization of citrate to iso-citrate. IRP1 assembles an aconitase-type $4 \mathrm{Fe}-4 \mathrm{~S}$ cluster in response to increased intracellular iron levels. The complex pathway involves several co-factors, such as Nfs1 (ISCS), frataxin, ISCU, glutaredoxin 5 (GLRX5) and others. Assembly of the $4 \mathrm{Fe}-4 \mathrm{~S}$ cluster alters the conformation of IRP1 and precludes IRE-binding (Dupuy et al., 2006; Walden et al., 2006). At the same time holo-IRP1 (containing the $4 \mathrm{Fe}-4 \mathrm{~S}$ cluster) acquires enzymatic activity as cytosolic aconitase, which 


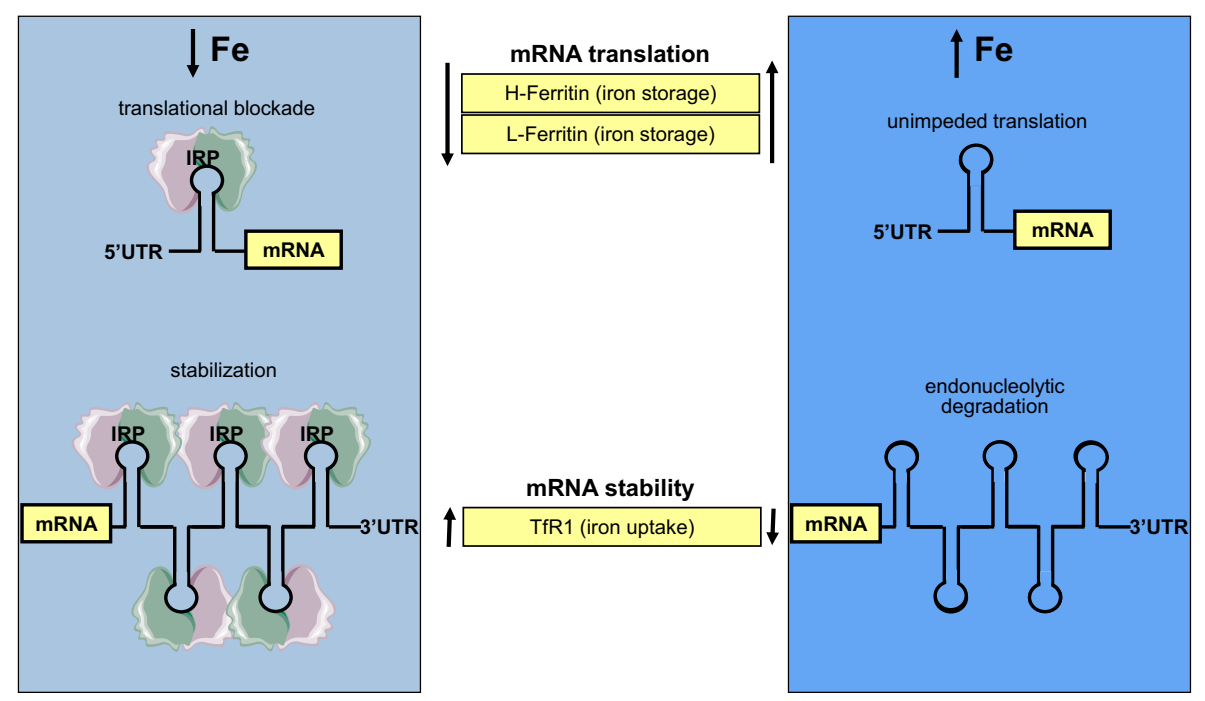

FIGURE 4 | Coordinate iron-dependent regulation of ferritin and TfR1 mRNA expression by IRE/IRP interactions. Iron deficiency promotes the binding of IRPs to cognate IREs in the untranslated regions of ferritin and
TfR1 mRNAs. These inhibit ferritin mRNA translation and stabilize TfR1 mRNA against endonucleolytic degradation. In iron-replete cells, IRPs do not bind to IREs, allowing ferritin mRNA translation and TfR1 mRNA degradation. is comparable to that of its mitochondrial counterpart. Iron starvation, as well as other signals, such as nitric oxide (NO) or hydrogen peroxide $\left(\mathrm{H}_{2} \mathrm{O}_{2}\right)$, promotes the loss of the $4 \mathrm{Fe}-4 \mathrm{~S}$ cluster and conversion of apo-IRP1 to an IRE-binding protein (Haile et al., 1992; Drapier et al., 1993; Weiss et al., 1993; Pantopoulos and Hentze, 1995). Thus, IRP1 is a bifunctional protein that is regulated by an unusual $4 \mathrm{Fe}-4 \mathrm{~S}$ cluster switch. Holo-IRP1 is stabilized by hypoxia and at oxygen concentrations ranging between 3 and $6 \%$, which reflect physiological tissue oxygenation (Meyron-Holtz et al., 2004b). Consistently with this notion, IRP1 predominates in the cytosolic aconitase form within tissues, but a fraction of apo-IRP1 is readily detectable by virtue of its IRE-binding activity (Meyron-Holtz et al., 2004a).

Contrary to IRP1, IRP2 does not bind an iron-sulfur cluster and is regulated at the level of protein stability. IRP2 accumulates in iron-starved and/or hypoxic cells, and undergoes proteasomal degradation in iron-replete oxygenated cells. Mechanistically, this involves ubiquitination of IRP2 by an E3 ubiquitin ligase complex consisting of the F-box protein FBXL5 and the auxiliary proteins SKP1, CUL1, and RBX1 (Salahudeen et al., 2009; Vashisht et al., 2009). FBXL5 exhibits genuine iron-sensing properties, as it is stabilized in the presence of iron and oxygen by forming a Fe-O-Fe center within its $\mathrm{N}$-terminal hemerythrinlike domain. Loss of this center in iron-starved and/or hypoxic cells exposes a degron via a conformational change (Chollangi et al., 2012; Thompson et al., 2012). This allows proteasomal degradation of FBXL5, which leads to concomitant accumulation of IRP2. Interestingly, FBXL5 can also promote the ubiquitination and degradation of IRP1 mutants that cannot form a 4Fe-4S cluster (Salahudeen et al., 2009; Vashisht et al., 2009). Proteasomal degradation of wild type apo-IRP1 under conditions of impairment of the iron-sulfur cluster assembly pathway has been proposed to operate as a reserve mechanism to control the
IRE-binding activity of IRP1 (Clarke et al., 2006; Wang et al., 2007).

\section{HUMAN DISEASES LINKED TO THE IRE/IRP SYSTEM}

Mutations in the IRE of L-ferritin mRNA that abrogate IRP binding are causatively linked to the hereditary hyperferritinemia-cataract syndrome (HHCS) (Beaumont et al., 1995). The hallmark of this disorder is overexpression of serum ferritin (up to 20-fold) in the absence of systemic iron overload or inflammation (Yin et al., 2014). Patients also have an increased tendency to develop bilateral cataract, which is possibly caused by accumulation of non-functional L-ferritin homopolymers in the lens (Levi et al., 1998). HHCS is transmitted in an autosomal dominant manner. Several HHCS-associated mutations in L-ferritin IRE have been described (Luscieti et al., 2013). Mutations affecting the loop structure or the $\mathrm{C}$ bulge result in the highest levels of serum ferritin and increased severity of cataract when compared with mutations in the stem structure of the IRE (Cazzola et al., 1997). Overall, the severity of the clinical phenotype appears to correlate with the degree of inhibition in IRP binding (Allerson et al., 1999). Nevertheless, the involvement of additional factors (genetic, environmental, inflammatory) has not been excluded (Roetto et al., 2002).

A point mutation (A49U) in the loop of $\mathrm{H}$-ferritin IRE has been associated with an autosomal dominant iron overload disorder in a Japanese family (Kato et al., 2001). Iron deposits were documented primarily in hepatocytes, but also in some Kupffer cells. The A49U mutation increased the affinity of IRPs for $\mathrm{H}$ ferritin IRE and suppressed $\mathrm{H}$-ferritin expression in cultured cells (Kato et al., 2001). Nevertheless, it remains unclear how this response promotes iron overload. The lack of follow-up studies to support the validity of these findings should also be noted.

Disruption of the zebrafish glrx5 gene, encoding glutaredoxin 5 , leads to constitutive activation of IRP1 for IRE-binding, due 


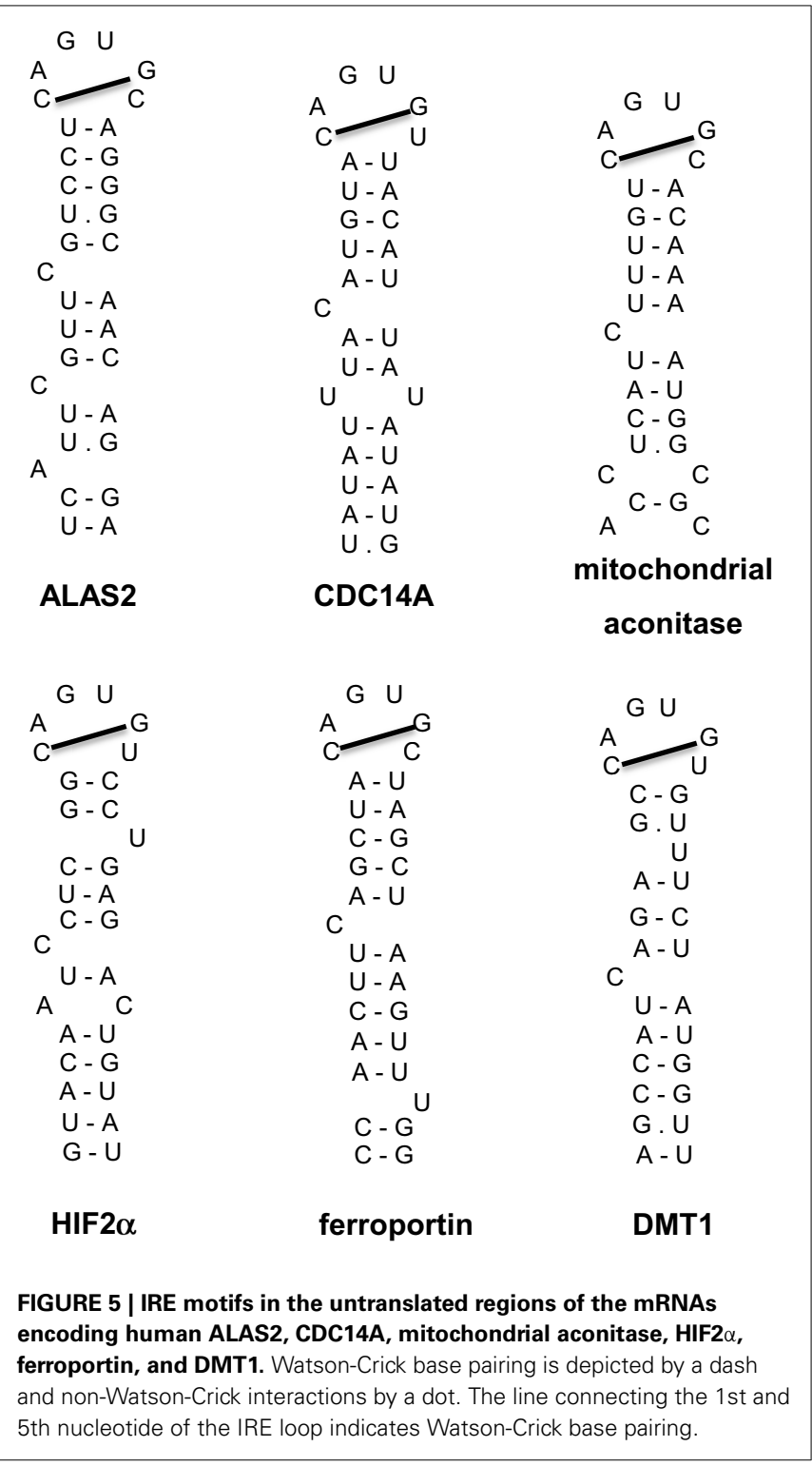

to defective assembly of its $4 \mathrm{Fe}-4 \mathrm{~S}$ cluster (Wingert et al., 2005). In a case report, a patient with GLRX5 deficiency developed a sideroblastic-like anemia with microcytosis and systemic iron overload (Camaschella et al., 2007). This disease is caused by IRP1-mediated suppression of ALAS2 mRNA translation, which results in impaired heme biosynthesis. A secondary effect is the depletion of cytosolic iron and the development of mitochondrial iron overload (Ye et al., 2010).

The above examples represent the only documented human disorders that are causatively linked to defects in the IRE/IRP system (Table 1). Genome-wide association studies (GWAS) showed that the IRP2 gene (IREB2) confers susceptibility to chronic obstructive pulmonary disease (COPD) (Demeo et al., 2009; Chappell et al., 2011; Zhou et al., 2012) and lies within a lung cancer-associated locus (Hansen et al., 2010; Cho et al., 2012; Fehringer et al., 2012). Apart from the identification of single nucleotide polymorphisms (SNPs) in IREB2, it was shown that COPD patients exhibit increased IRP2 mRNA and protein expression (Demeo et al., 2009) and it was speculated that this may contribute to iron accumulation in the lungs. IREB2 polymorphisms have also been associated with Alzheimer's disease (Coon et al., 2006). Interestingly, biochemical studies showed that IRP1 selectively regulates translation of amyloid precursor protein (APP) mRNA by binding to an atypical putative IRE motif (Cho et al., 2010), which may provide another connection of the IRE/IRP system with Alzheimer's disease. The IRP1 gene (ACO1) has been associated with cutaneous malignant melanoma (Yang et al., 2010) and neuropathic pain in HIV-infected patients (Kallianpur et al., 2014), while the IRE-binding activity of IRP1 was reported to be increased in Friedreichs' ataxia (Lobmayr et al., 2005) and in Parkinson's disease (Faucheux et al., 2002). Finally, polymorphisms in both ACO1 and IREB2 have been linked to agerelated macular degeneration (Synowiec et al., 2012). GWAS data with ACO1 and IREB2 are summarized in Table 2. The molecular mechanisms by which IRPs may contribute to pathogenesis of the above disorders remain to be established.

\section{MOUSE MODELS WITH UBIQUITOUS ABERRATION IN THE IRE/IRP SYSTEM}

Mice with ubiquitous ablation of both Irp1 and Irp2 cannot be generated because the embryos do not survive the blastocyst stage, possibly due to misregulation of iron metabolism (Smith et al., 2006). These data highlight the physiological significance of the IRE/IRP system in early development. On the other hand, single Irp $1^{-/-}$or Irp $2^{-/-}$mice are viable. At first glance, this suggests that Irp1 and Irp2 share overlapping functions in vivo. Nonetheless, Irp1 $1^{-/-}$and Irp2 $2^{-/-}$mice manifest distinct phenotypes, indicating variable target specificity. The phenotypic features of current mouse models with global or tissue-specific "loss" or "gain" of Irp1 and/or Irp2 functions are summarized in Table 3.

Irp1 $1^{-/-}$mice were initially reported to lack any overt abnormalities (Meyron-Holtz et al., 2004a; Galy et al., 2005a). Because they merely misregulated ferritin and TfR 1 expression in the kidney and the brown fat, tissues with the highest abundance of IRP1, it was proposed that Irp2 dominates cellular iron metabolism in tissues, with Irp1 having an auxiliary physiological function (Meyron-Holtz et al., 2004a). In addition, Irp1 $1^{-/-}$ (and Irp $2^{-/-}$) mice did not exhibit any defects when challenged with turpentine to induce an inflammatory response (Viatte et al., 2009), despite the fact that IRPs are modulated in cultured cells by inflammatory reactive species such as $\mathrm{H}_{2} \mathrm{O}_{2}$ and $\mathrm{NO}$ (Weiss et al., 1993; Pantopoulos and Hentze, 1995; Wang et al., 2005; Hausmann et al., 2011).

Recently, Irp1 $1^{-/-}$mice were documented to develop polycythemia and pathological iron metabolism due to stress erythropoiesis, as well as pulmonary hypertension and cardiac hypertrophy and fibrosis (Anderson et al., 2013; Ghosh et al., 2013; Wilkinson and Pantopoulos, 2013). These phenotypes are attributed to relief of translational suppression of Hif $2 \alpha$ mRNA, which leads to transcriptional activation of the downstream Hif $2 \alpha$ targets erythropoietin and endothelin-1. Thus, murine Irp1 operates as specific regulator of the Hif $2 \alpha$ IRE, in agreement with previous in vitro data (Zimmer et al., 2008). Irp1 $1^{-/-}$mice exhibit 
Table 1 | Human disorders that are causatively linked to defects in the IRE/IRP system.

\begin{tabular}{|c|c|c|c|}
\hline Human disease & Mutation & Phenotype & References \\
\hline $\begin{array}{l}\text { Hereditary } \\
\text { hyperferritinemia-cataract } \\
\text { syndrome (HHCS) }\end{array}$ & $\begin{array}{l}\text { Mutations in the IRE of L-ferritin mRNA } \\
\text { that impair IRP binding }\end{array}$ & $\begin{array}{l}\text { Overexpression of serum ferritin in the } \\
\text { absence of systemic iron overload or } \\
\text { inflammation. Tendency for the } \\
\text { development of bilateral cataract }\end{array}$ & $\begin{array}{l}\text { (Beaumont et al., 1995; other } \\
\text { papers identified further } \\
\text { mutations) }\end{array}$ \\
\hline $\begin{array}{l}\text { Iron overload disorder } \\
\text { with autosomal dominant } \\
\text { transmission }\end{array}$ & $\begin{array}{l}\text { Point mutation in the IRE loop of } \mathrm{H} \text {-ferritin } \\
\text { that increases IRP binding }\end{array}$ & $\begin{array}{l}\text { Suppression of } \mathrm{H} \text {-ferritin leading to an iron } \\
\text { overload disorder phenotypically related to } \\
\text { hemochromatosis }\end{array}$ & Kato et al., 2001 \\
\hline $\begin{array}{l}\text { Sideroblastic-like anemia } \\
\text { with iron overload }\end{array}$ & $\begin{array}{l}\text { GLRX5 deficiency leading to increased } \\
\text { IRE-binding activity of IRP1 and } \\
\text { suppression of ALAS2 mRNA translation }\end{array}$ & $\begin{array}{l}\text { Development of a sideroblastic-like } \\
\text { anemia with microcytosis and systemic } \\
\text { iron overload }\end{array}$ & Camaschella et al., 2007 \\
\hline
\end{tabular}

Table 2 | Genome-wide association studies (GWAS) with the IRPI and IRP2 genes, ACO1 and IREB2, respectively.

\begin{tabular}{|c|c|c|c|}
\hline Gene & Disease & Association & References \\
\hline IREB2 & $\begin{array}{l}\text { Chronic obstructive } \\
\text { pulmonary disease (COPD) }\end{array}$ & $\begin{array}{l}\text { Patients with COPD have increased IRP2 mRNA and } \\
\text { protein expression in addition to a single nucleotide } \\
\text { polymorphism in IREB2 }\end{array}$ & $\begin{array}{l}\text { Demeo et al., 2009; Chappell et al., } \\
\text { 2011; Zhou et al., } 2012\end{array}$ \\
\hline IREB2 & Lung cancer & Lies within a cancer-associated locus & $\begin{array}{l}\text { Hansen et al., 2010; Cho et al., 2012; } \\
\text { Fehringer et al., } 2012\end{array}$ \\
\hline IREB2 & Alzheimer's disease & $\begin{array}{l}\text { IREB2 polymorphism have been associated with } \\
\text { Alzheimer's disease }\end{array}$ & Coon et al., 2006 \\
\hline ACO1 & $\begin{array}{l}\text { Neuropathic pain in } \\
\text { HIV-infected patients }\end{array}$ & $\begin{array}{l}\text { ACO1 was significantly associated with distal } \\
\text { neuropathic pain and pain severity in HIV-infected } \\
\text { patients on antiretroviral therapy }\end{array}$ & Kallianpur et al., 2014 \\
\hline ACO1 & $\begin{array}{l}\text { Cutaneous malignant } \\
\text { melanoma(CMM) }\end{array}$ & $\begin{array}{l}\text { ACO1 was significantly associated with } \mathrm{CMM} \text { and } \\
\text { training ability }\end{array}$ & Yang et al., 2010 \\
\hline $\begin{array}{l}\text { ACO1 and } \\
\text { IREB2 }\end{array}$ & Macular degeneration & $\begin{array}{l}\text { Polymorphisms in both } A C O 1 \text { and IREB2 have been } \\
\text { linked to age related macular degeneration }\end{array}$ & Synowiec et al., 2012 \\
\hline
\end{tabular}

high mortality when placed on an iron-deficient diet, which is known to stabilize Hif2 $\alpha$, due to abdominal hemorrhages (Ghosh et al., 2013). When Irp1 $1^{-/-}$mice are fed with a standard diet, polycythemia attenuates after the 10th week of age (Wilkinson and Pantopoulos, 2013), possibly due to enhanced Hif $2 \alpha$ degradation by the pVHL pathway. This may explain why their pathology escaped attention in the past.

Irp2 $2^{-/-}$mice develop microcytic hypochromic anemia and erythropoietic protoporphyria, associated with relatively mild duodenal and hepatic iron overload and splenic iron deficiency (Cooperman et al., 2005; Galy et al., 2005b). They exhibit a low Tfr 1 content and express high levels of protoporphyrin IX in erythroid precursor cells. A closer look on the role of Irp1 and Irp2 in erythropoiesis, duodenal iron absorption and systemic iron metabolism will be provided in the next sections.

Global Irp2 $2^{-/-}$deficiency has also been associated with progressive neurodegeneration, loss of Purkinje neurons and iron overload in white matter areas of the brain (LaVaute et al., 2001; Ghosh et al., 2006), with more severe presentation in Irp1 haploinsufficient Irp1 ${ }^{+/-} \operatorname{Irp} 2^{-/-}$mice (Smith et al., 2004). The neuronal pathology of Irp2 $2^{-/-}$mice can be partially rescued by pharmacological activation of endogenous Irp1 for IRE-binding (Ghosh et al., 2008). Mechanistically, the pathology may be caused by functional iron deficiency in neuronal cells due to derepression of ferritin mRNA translation, which could result in enhanced iron storage and reduced availability for metabolic purposes (Jeong et al., 2011). This scenario is reminiscent of neuroferritinopathy, a neurodegenerative disease caused by expression of mutant L-ferritin (Burn and Chinnery, 2006). Suppression of Tfr1 and enhancement of ferroportin expression in Irp2 $2^{-/-}$neurons could also contribute to pathology. Nevertheless, isogenic Irp2 $2^{-/-}$mice generated by another strategy did not develop any signs of neurodegeneration but rather manifested minor performance deficits in specific neurological tests (motor coordination and balance) (Galy et al., 2006). A third independent $\operatorname{Irp} 2^{-/-}$ mouse strain was recently generated and analyzed, corroborating the abnormalities in erythropoiesis and brain iron metabolism of these animals; the latter were linked to mild neurological and 
Table 3 | Phenotypic features of mouse models with global or tissue-specific "loss" or "gain" of Irp1 and/or Irp2 functions.

\begin{tabular}{|c|c|c|c|c|}
\hline Mouse model & $\begin{array}{l}\text { Site of } \\
\text { modification }\end{array}$ & Generation credit & Phenotype & Phenotype credit \\
\hline \multirow[t]{6}{*}{ Irp1-/- } & \multirow[t]{6}{*}{ Global } & \multirow[t]{6}{*}{$\begin{array}{l}\text { Meyron-Holtz et al., 2004a; } \\
\text { Galy et al., } 2004\end{array}$} & $\begin{array}{l}\text { Polycythemia, stress erythropoiesis, } \\
\text { splenomegaly, and increased } \\
\text { expression of erythropoietin }\end{array}$ & $\begin{array}{l}\text { Anderson et al., 2013; } \\
\text { Ghosh et al., 2013; } \\
\text { Wilkinson and } \\
\text { Pantopoulos, } 2013\end{array}$ \\
\hline & & & $\begin{array}{l}\text { Pulmonary hypertension, cardiac } \\
\text { hypertrophy and cardiac fibrosis. Mice } \\
\text { succumb to hemorrhages when fed } \\
\text { an iron-deficient diet }\end{array}$ & Ghosh et al., 2013 \\
\hline & & & $\begin{array}{l}\text { Increased expression of Dmt1, } \\
\text { ferroportin and Dcytb mRNAs in the } \\
\text { duodenum }\end{array}$ & Anderson et al., 2013 \\
\hline & & & $\begin{array}{l}\text { Misregulation ferritin and } \mathrm{Tfr} 1 \\
\text { expression in the kidney and brown fat }\end{array}$ & $\begin{array}{l}\text { Meyron-Holtz et al., } \\
2004 a\end{array}$ \\
\hline & & & $\begin{array}{l}\text { Efficient inflammatory signaling } \\
\text { response to turpentine }\end{array}$ & Viatte et al., 2009 \\
\hline & & & $\begin{array}{l}\text { Increased ferroportin expression on } \\
\text { splenic macrophages and decreased } \\
\text { hepcidin mRNA levels in the liver }\end{array}$ & $\begin{array}{l}\text { Wilkinson and } \\
\text { Pantopoulos, } 2013\end{array}$ \\
\hline \multirow[t]{8}{*}{ Irp2 $2^{-/-}$} & \multirow[t]{8}{*}{ Global } & \multirow[t]{8}{*}{$\begin{array}{l}\text { LaVaute et al., 2001; Galy et al., } \\
\text { 2004; Zumbrennen-Bullough } \\
\text { et al., } 2014\end{array}$} & $\begin{array}{l}\text { Microcytic hypochromic anemia with } \\
\text { mild duodenal and hepatic iron } \\
\text { overload and splenic iron deficiency }\end{array}$ & $\begin{array}{l}\text { Cooperman et al., 2005; } \\
\text { Galy et al., 2005b }\end{array}$ \\
\hline & & & $\begin{array}{l}\text { Reduced TfR1 expression in erythroid } \\
\text { precursors }\end{array}$ & $\begin{array}{l}\text { Cooperman et al., 2005; } \\
\text { Galy et al., 2005b }\end{array}$ \\
\hline & & & $\begin{array}{l}\text { High levels of protoporphyrin IX in } \\
\text { erythroid precursors }\end{array}$ & Cooperman et al., 2005 \\
\hline & & & Increased ferritin levels in all tissues & Cooperman et al., 2005 \\
\hline & & & $\begin{array}{l}\text { Iron overload in neurons and } \\
\text { progressive neurodegeneration }\end{array}$ & $\begin{array}{l}\text { LaVaute et al., 2001; } \\
\text { Ghosh et al., } 2006\end{array}$ \\
\hline & & & $\begin{array}{l}\text { Efficient inflammatory signaling } \\
\text { response to turpentine }\end{array}$ & Viatte et al., 2009 \\
\hline & & & $\begin{array}{l}\text { Mild neurological and behavioral } \\
\text { defects, as well as nociception }\end{array}$ & $\begin{array}{l}\text { Zumbrennen-Bullough } \\
\text { et al., } 2014\end{array}$ \\
\hline & & & $\begin{array}{l}\text { Minor performance deficits in specific } \\
\text { neurological tests (motor coordination } \\
\text { and balance) }\end{array}$ & Galy et al., 2006 \\
\hline $\operatorname{Irp} 2^{-/-}$ & Liver-specific & Ferring-Appel et al., 2009 & Mild hepatic iron overload & Ferring-Appel et al., 2009 \\
\hline $\operatorname{lrp} 2^{-/-}$ & $\begin{array}{l}\text { Intestinal- } \\
\text { specific }\end{array}$ & Ferring-Appel et al., 2009 & Mild duodenal iron overload & Ferring-Appel et al., 2009 \\
\hline $\operatorname{lrp} 2^{-/-}$ & $\begin{array}{l}\text { Macrophage- } \\
\text { specific }\end{array}$ & Ferring-Appel et al., 2009 & No pathology & Ferring-Appel et al., 2009 \\
\hline $\operatorname{Irp} 1^{-/-} \mid r p 2^{-/-}$ & Global & Smith et al., 2006 & $\begin{array}{l}\text { Embryonic lethality at the blastocyst } \\
\text { stage of development }\end{array}$ & Smith et al., 2006 \\
\hline \multirow[t]{2}{*}{$\left|r p 1^{+/-}\right| r p 2^{-/-}$} & \multirow[t]{2}{*}{ Global } & \multirow[t]{2}{*}{ Smith et al., 2004} & $\begin{array}{l}\text { More serve presentation of neuronal } \\
\text { pathology than that of Irp2 } 2^{-/-} \text {mice }\end{array}$ & Smith et al., 2004 \\
\hline & & & $\begin{array}{l}\text { Neuronal pathology partially rescued } \\
\text { by the pharmacological activation of } \\
\text { endogenous Irp1 }\end{array}$ & Ghosh et al., 2008 \\
\hline
\end{tabular}


Table 3 | Continued

\begin{tabular}{|c|c|c|c|c|}
\hline Mouse model & $\begin{array}{l}\text { Site of } \\
\text { modification }\end{array}$ & Generation credit & Phenotype & Phenotype credit \\
\hline Irp1-/-Irp2-/- & Liver-specific & Galy et al., 2010 & $\begin{array}{l}\text { Early lethality within } 1-2 \text { weeks after } \\
\text { birth due to liver failure }\end{array}$ & Galy et al., 2010 \\
\hline Irp1-/-Irp2-/- & $\begin{array}{l}\text { Intestinal- } \\
\text { specific }\end{array}$ & Galy et al., 2008 & $\begin{array}{l}\text { Growth retardation, early death } \\
\text { (within } 30 \text { days) due to dehydration. } \\
\text { Increased expression of ferritin, } \\
\text { ferroportin, and Dmt1 }\end{array}$ & Galy et al., 2008 \\
\hline $\operatorname{Irp} 1^{-/-} \mid r p 2^{-/-}$ & $\begin{array}{l}\text { Adult } \\
\text { ligand-induced } \\
\text { intestinal- } \\
\text { specific }\end{array}$ & Galy et al., 2013 & $\begin{array}{l}\text { Increased expression of ferritin } \\
\text { leading to "mucosal block," in spite of } \\
\text { increased expression of ferroportin } \\
\text { and Dmt1 }\end{array}$ & Galy et al., 2013 \\
\hline $\begin{array}{l}\text { Irp1 "gain of } \\
\text { function" due to } \\
\text { expression of a } \\
\text { constitutive IRP1 } \\
\text { transgene }\end{array}$ & Global & Casarrubea et al., 2013 & $\begin{array}{l}\text { Macrocytic erythropenia due to } \\
\text { impaired erythroid differentiation }\end{array}$ & Casarrubea et al., 2013 \\
\hline $\begin{array}{l}\text { Irp2 "gain of } \\
\text { function" due to } \\
\text { disruption of FbxI5 }\end{array}$ & Global & $\begin{array}{l}\text { Moroishi et al., 2011; Ruiz et al., } \\
2013\end{array}$ & Embryonic lethality & $\begin{array}{l}\text { Moroishi et al., 2011; Ruiz } \\
\text { et al., } 2013\end{array}$ \\
\hline $\begin{array}{l}\text { Irp2 "gain of } \\
\text { function" due to } \\
\text { disruption of FbxI5 }\end{array}$ & Liver-specific & Moroishi et al., 2011 & $\begin{array}{l}\text { Hepatic iron overload and } \\
\text { steatohepatitis; low hepcidin mRNA } \\
\text { levels. Mice succumb to lethal liver } \\
\text { failure when fed a high-iron diet }\end{array}$ & $\begin{array}{l}\text { Moroishi et al., 2011; Ruiz } \\
\text { et al., } 2013\end{array}$ \\
\hline
\end{tabular}

behavioral defects, as well as nociception (Zumbrennen-Bullough et al., 2014). The discrepancies in the phenotypes of the three Irp $2^{-/-}$mouse lines may be related to the targeting strategies and their impact on flanking genomic sequences, genetic factors, and possibly also environmental factors.

Ubiquitous Irp1 "gain of function" mice were generated by the transgenic expression of a constitutively active IRP1 mutant from the Rosa26 locus (Casarrubea et al., 2013). Expression of the transgene was relatively low and the mice developed erythropoietic abnormalities (macrocytic erythropenia due to impaired erythroid differentiation).

The targeted disruption of Fbxl5 could yield ubiquitous Irp2 "gain of function" mice. Nevertheless, Fbxl5 $5^{-/-}$mice are not viable and die during embryogenesis (Moroishi et al., 2011; Ruiz et al., 2013). This phenotype is rescued by concomitant disruption of Irp2, but not Irp1, indicating that the major physiological function of Fbxl5 is to regulate Irp2.

\section{THE IRE/IRP SYSTEM IN ERYTHROPOIESIS}

Most iron in the body is utilized in erythropoiesis, a process that occurs mainly in the bone marrow of humans and in the bone marrow and spleen of mice (Cavill, 2002). Erythroid precursor cells express high levels of TfR1 and consume the majority of Tf-bound iron for the production of heme, the oxygen-binding moiety of hemoglobin (Ponka, 1997). An adult human produces about 2 million RBCs per second. Increased erythropoietic drive is known to stimulate iron absorption (Finch, 1994).
This is mediated by suppression of hepcidin expression, which allows increased iron efflux to the bloodstream from duodenal enterocytes and tissue macrophages (Ganz, 2013). During iron deficiency, erythroid precursor cells will have priority for iron utilization, for the production of RBCs, over cells in other tissues (Finch, 1994). Maturation of erythroid cell is induced by erythropoeitin (EPO), a circulating glycoprotein hormone that prevents apoptosis of erythroid progenitor cells (Koury and Bondurant, 1990). EPO is primarily synthesized in peritubular interstitial fibroblasts of the kidney, and to a smaller extent in hepatocytes of the liver. Murine Epo is transcriptionally activated during hypoxemia by Hif2 $\alpha$ (Rankin et al., 2007; Kapitsinou et al., 2010), while Hif $\alpha$ indirectly suppresses hepcidin expression by stimulating erythropoiesis via Epo (Liu et al., 2012; Mastrogiannaki et al., 2012). There are several points where the IRE/IRP system regulates erythropoiesis.

First, the phenotype of Irp1 $1^{-/-}$mice demonstrates that Irp1 operates as a key upstream regulator of Hif $2 \alpha$ expression at the level of mRNA translation (Anderson et al., 2013; Ghosh et al., 2013; Wilkinson and Pantopoulos, 2013). Essentially, these animals exhibit features of Hif $2 \alpha$ overexpression, which are also manifested in patients with Chuvash polycythemia (Ang et al., 2002), and other forms of familial polycythemia caused by "gain of function" HIF2 $\alpha$ mutations (Percy et al., 2008), or inactivating mutations in pVHL, a negative regulator of HIF $2 \alpha$ stability (Percy et al., 2006). One of them, is hyperproduction of Epo, which causes splenomegaly due to extramedullary erythropoiesis, 
promotes expansion of late stage basophilic erythroblasts, as well as polychromatic and orthochromatic erythroblasts, and finally leads to reticulocytosis and polycythemia. Importantly, overexpression of hepatic Epo is rescued by intercrossing $\operatorname{Irp} 1^{-/-}$and liver-specific Hif $2 \alpha^{-/-}$mice (Wilkinson and Pantopoulos, 2013). On the other hand, the defects in erythroid differentiation documented in the constitutive IRP1 transgenic mice can be attributed to reduced Hif $2 \alpha$ expression (Casarrubea et al., 2013). Hence, the translational regulation of HIF $2 \alpha$ mRNA by IRP1 links iron metabolism with erythropoiesis via EPO. Physiologically, this response probably serves to contain EPO expression and subsequent stimulation of erythropoiesis under conditions of iron deficiency. In addition, it is tempting to speculate that stress activation of IRP1 (by $\mathrm{H}_{2} \mathrm{O}_{2}$ or NO) (Weiss et al., 1993; Pantopoulos and Hentze, 1995) may contribute to the impairment of EPO production that is frequently observed under chronic inflammatory conditions or in chronic kidney disease (Weiss and Goodnough, 2005), via suppression of HIF $2 \alpha$ mRNA translation.

The above data suggest that IRP1 functions as an iron and oxygen sensor (Figure 6). According to this model, in normoxic renal interstitial fibroblasts the small steady-state fraction of apoIRP1 inhibits HIF $2 \alpha$ mRNA translation and thereby limits EPO production to physiological levels. This fraction is expected to increase in normoxic iron deficiency due to $4 \mathrm{Fe}-4 \mathrm{~S}$ cluster disassembly, further suppressing HIF $2 \alpha$ and EPO expression as a homeostatic response to reduced iron availability, consistently with iron-restricted erythropoiesis. Conversely, increased iron supply is expected to increase the abundance of holo-IRP1, allowing de-repression of HIF $2 \alpha$ mRNA translation. This response is also favored by hypoxia, which is known to stabilize holo-IRP1. Thus, in hypoxic and/or iron-replete renal interstitial fibroblasts, unimpeded HIF $2 \alpha$ mRNA translation leads to increased generation of EPO and thereby stimulates erythropoiesis, as a homeostatic adaptation to the scarcity of oxygen and/or the abundance of iron.

IRP2 is not involved in the regulation of HIF $2 \alpha$ mRNA in vivo. This makes physiological sense, since IRP2 is highly active under hypoxia, when HIF2 $\alpha$ synthesis is required. Nevertheless, the phenotype of Irp2 $2^{-/-}$mice suggests that IRP2 is a critical regulator of other erythropoietic pathways. These animals present with hypochromic microcytic anemia with reduced iron availability for erythropoiesis (Cooperman et al., 2005; Galy et al., 2005b; Zumbrennen-Bullough et al., 2014). This is not a result of global iron deficiency but rather misregulation of cellular iron traffic. Irp $2^{-/-}$erythroid cells exhibit a reduced Tfr1 content, apparently due to lack of Tfr1 mRNA stabilization in the absence of Irp2. As a result, these cells fail to acquire sufficient amounts of iron for erythropoiesis, in spite of the physiological iron supply, which is reflected in the normal Tf saturation and total ironbinding capacity (TIBC) in serum. Therefore, Irp2 appears to act as major activator of Tfr1 in erythroid cells. It is conceivable that this function is more pronounced at earlier stages of erythroid development, considering that during terminal erythroid differentiation, Tfr1 mRNA stability remains unresponsive to iron, bypassing the IRE/IRP checkpoint (Schranzhofer et al., 2006).

Irp2 $2^{-1-}$ mice also manifest very high levels of free and zinc protoporphyrin IX in RBCs $(\sim 200$-fold increase for free protoporphyrin IX), consistently with erythropoietic protoporphyria (Cooperman et al., 2005). This is very likely caused by enhanced heme biosynthetic activity due to de-repression of Alas2 mRNA translation. In the absence of adequate iron, it results in accumulation of free protoporphyrin IX and in incorporation of zinc in the protoporphyrin IX ring. Therefore, IRP2 also acts as a major regulator of ALAS2 mRNA translation via the IRE in its $5^{\prime}$ UTR. The interpretation that IRP2 regulates erythroid iron uptake and utilization by controlling expression of the IRE-containing TfR1 and ALAS2 mRNAs, respectively, is also supported by data with tissue-specific Irp $2^{-/-}$mice. Thus, liveror intestinal-specific ablation of Irp2 recapitulates the iron overload phenotype of these tissues in ubiquitous Irp $2^{-/-}$mice, but fails to promote microcytic anemia (Ferring-Appel et al., 2009).

\section{THE IRE/IRP SYSTEM IN DIETARY IRON ABSORPTION}

Dietary iron absorption takes place in brush border enterocytes of the duodenum, especially in the upper tract. The pathway is highly regulated at different levels. Hormonal regulation via hepcidin is well established. Hepcidin is produced in the liver in response to high serum or hepatic iron (Corradini et al., 2011; Ramos et al., 2011) and limits further iron absorption by promoting the degradation of duodenal ferroportin (Nemeth et al., 2004; Chung et al., 2009), the basolateral iron transporter. Hepcidin may also promote degradation of DMT1, the apical iron transporter, by the proteasome (Chung et al., 2009; Brasse-Lagnel et al., 2011). Both ferroportin (Taylor et al., 2011) and DMT1 (Mastrogiannaki et al., 2009; Shah et al., 2009) are transcriptionally activated in iron-deficient enterocytes by HIF $2 \alpha$. In addition, ferroportin and DMT1 could be directly regulated by IRPs at the levels of mRNA translation or stability, respectively. Duodenal enterocytes also express ferritin, which limits excessive iron transfer to the circulation (Vanoaica et al., 2010). TfR1 expression is restricted to non-absorptive enterocytes in the intestinal crypts (Waheed et al., 1999).

Iron deficiency elicits multiple and antagonistic signals on duodenal ferroportin: transcriptional activation of its gene via HIF $2 \alpha$ (which is negatively regulated by IRP1), translational repression of its mRNA via IRPs, and stabilization of the protein via downregulation of hepcidin. The net result is induction of ferroportin, which is considered a physiologic response to increase iron supply to the bloodstream (McKie et al., 2000). It has been proposed that the IRP blockade can be bypassed via enriched expression of an alternatively spliced non-IRE containing ferroportin transcript (Zhang et al., 2009). Nevertheless, in other reports the canonical IRE-containing ferroportin mRNA was found to be predominant in the duodenum of rats and mice (Darshan et al., 2011; Galy et al., 2013). Another possibility is that protein stabilization due to suppression of hepcidin is dominant.

Likewise, iron deficiency elicits multiple and antagonistic signals on duodenal DMT1: transcriptional activation of its gene via HIF $2 \alpha$ (which is negatively regulated by IRP1), possible stabilization of its IRE-containing transcripts by IRPs, and possible stabilization of the protein via downregulation of hepcidin. Again, the net result is induction of DMT1 (Gunshin et al., 1997), which serves to increase dietary iron absorption from the intestinal lumen. Four different DMT1 mRNA isoforms are generated 

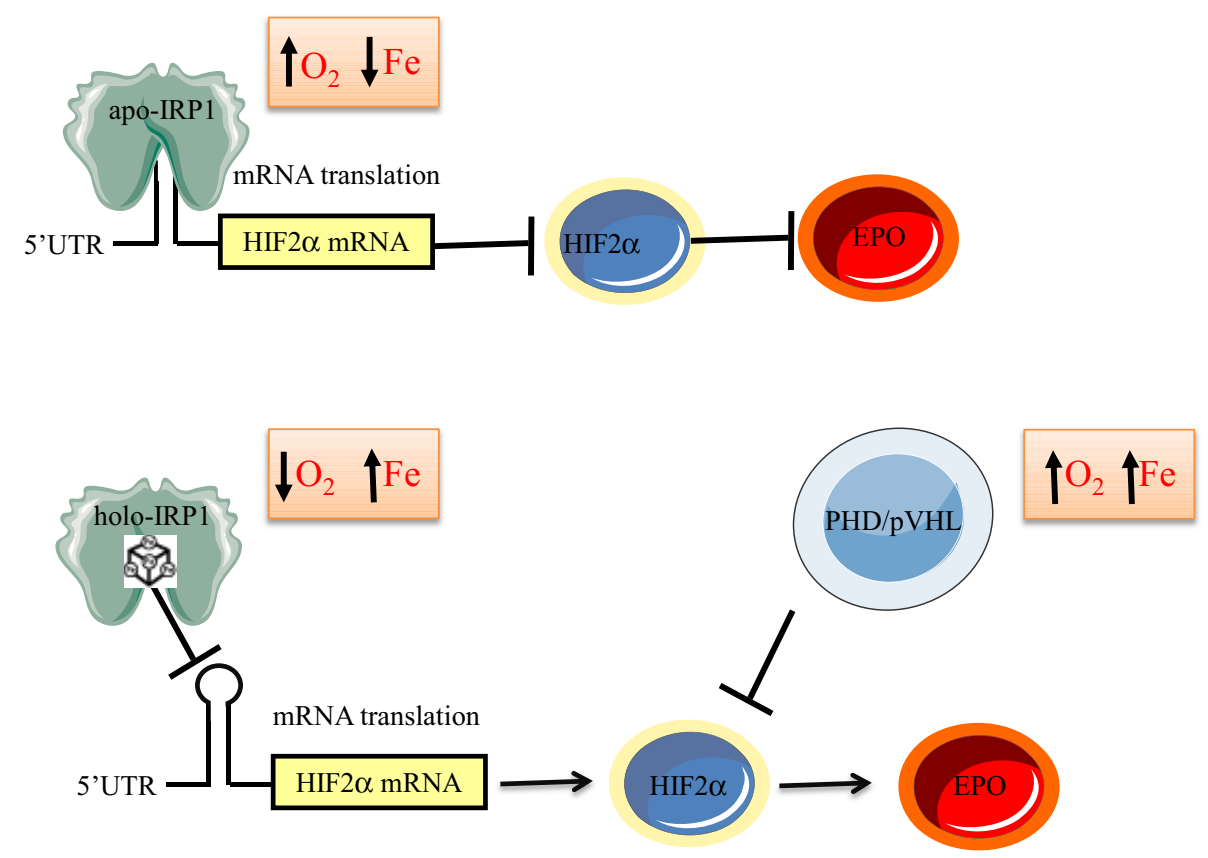

FIGURE 6 | Model for regulation of erythropoiesis by IRP1 via the HIF2 $\alpha$ /EPO axis. In iron-deficient or normoxic cells, apo-IRP1 limits HIF2 $\alpha$ synthesis by binding to HIF2 $\alpha$ mRNA. Iron-replete conditions favor conversion of apo- to holo-IRP1, at the expense of its IRE-binding activity, allowing HIF2 $\alpha$ mRNA translation and transcriptional activation of its downstream target EPO. Hypoxia stabilizes holo-IRP1. Accumulation of HIF $2 \alpha$ is antagonized by the PHD/pVHL degradation system, which is activated by oxygen and iron. by the combination of alternative promoter usage and alternative splicing, and two of them harbor an IRE (Hubert and Hentze, 2002). Interestingly, the IRE-containing DMT1 mRNAs predominate in the duodenum and their expression is induced in iron deficiency (Canonne-Hergaux et al., 1999; Hubert and Hentze, 2002). Their transcription is selectively activated by HIF2 $\alpha$ (Mastrogiannaki et al., 2009; Shah et al., 2009).

Experiments with mice bearing global or enterocyte-specific Irp deficiencies provided insights on the role of the IRE/IRP system in dietary iron absorption. Irp $1^{-/-}$mice express high levels of duodenal ferroportin and IRE-Dmt1 mRNAs, most likely as a result of de-repression of Hif $2 \alpha$ mRNA translation and enhanced Hif $2 \alpha$ transcriptional activity in this tissue (Anderson et al., 2013). This interpretation is consistent with the high expression of further Hif $2 \alpha$ target genes. Ferroportin and Dmt1 expression was not altered in duodena of Irp2 $2^{-/-}$mice, which exhibit iron overload and express high levels of ferritin (Galy et al., 2005b). High levels of duodenal ferritin were also documented in mice with enterocyte-specific disruption of Irp2 (Ferring-Appel et al., 2009). On the other hand, duodenal ferritin was not suppressed in mice expressing the constitutive IRP1 transgene (Casarrubea et al., 2013), in agreement with previous cell culture experiments (Wang and Pantopoulos, 2002), possibly due to alternative ferritin mRNA translation via internal initiation (Daba et al., 2012). Thus, IRP2 alone appears to function as an important regulator of ferritin but not ferroportin and DMT1 in the duodenum.

Mouse pups with enterocyte-specific deletion of both Irp1 and Irp2 are viable at birth but die within 4 weeks due to malabsorption and dehydration, associated with abnormalities in intestinal architecture (Galy et al., 2008). Their enterocytes manifested highly increased expression of ferritin and ferroportin, and reduced levels of Tfr1 and Dmt1. The downregulation of ferritin and ferroportin was not associated with alterations in their mRNA levels, reinforcing the role of IRPs in the regulation of duodenal ferritin synthesis, but also demonstrating a prominent function of the IRE/IRP system in translational control of duodenal ferroportin mRNA. Expression of the major IRE-Dmt1 mRNA isoform was slightly reduced in the mutant mice, providing first in vivo evidence for a role of IRPs in the control of IRE-DMT1 mRNA stability.

Adult mice with enterocyte-specific ablation of both Irp 1 and Irp2 were generated by using a tamoxifen-inducible Cre-deleter strain under the control of the villin promoter (Galy et al., 2013). These animals are viable and the ablation of Irps does not significantly alter intestinal architecture. As expected, the expression of ferritin and ferroportin was very high, while Tfr1 levels were low. Dmtl was also upregulated, in contrast to the data obtained in pups with enterocyte-specific deletion of both Irps (Galy et al., 2008). The induction of Dmtl was associated with an increase in steady-state levels of the IRE-Dmt1 mRNA isoforms, which was attributed to transcriptional stimulation by Hif $2 \alpha$. Together, the above data suggest that Irps regulate the IREDmt 1 mRNA only in newborn mice but not in adult animals. This is consistent with the notion that duodenal iron absorption in suckling pups is enhanced to satisfy metabolic needs of the rapidly growing organism, and is not subjected to negative 
regulation by hepcidin (Darshan et al., 2011). Stabilization of the IRE-Dmt1 mRNA isoforms by Irps could contribute to the increased iron absorption capacity before weaning. Surprisingly, adult mice with enterocyte-specific ablation of both Irps exhibited impaired iron absorption, in spite of the profound induction of the apical and basolateral iron transporters. This was attributed to a "mucosal block" imposed by the overexpression of ferritin, which stores internalized iron and prevents its delivery to the bloodstream. Therefore, alleviation of the "mucosal block" by limiting the expression of ferritin emerges as a crucial function of IRPs, possibly with a major contribution of IRP2, in enterocytes (Figure 7).

\section{THE IRE/IRP SYSTEM IN SYSTEMIC IRON METABOLISM}

Systemic iron metabolism is regulated by hepcidin, a peptide hormone synthesized by liver hepatocytes, which targets ferroportin in duodenal enterocytes, tissue macrophages and other ironexporting cells (Ganz, 2013). The IRE/IRP system appears to intersect with the hepcidin ferroportin axis. Young $\operatorname{Irp} 1^{-/-}$ mice exhibit a marked suppression of hepcidin mRNA, accompanied by accumulation of ferroportin in splenic macrophages (Wilkinson and Pantopoulos, 2013). This response is caused by the increased erythropoietic activity of these animals due to induction of Hif $2 \alpha$ and Epo, which is an established and potent inhibitor of hepcidin expression (Ganz, 2013). Irp2 ${ }^{-/-}$mice were found to have physiological hepcidin mRNA levels, in spite of hepatic iron overload (Cooperman et al., 2005; Galy et al., 2005b). However, at the age of 4-6 weeks, these animals showed a significant induction of hepcidin mRNA expression (Wilkinson and Pantopoulos, 2013). Conceivably, these seemingly discrepant findings are related to the antagonistic signals of erythropoietic drive and iron overload, which act as negative or positive

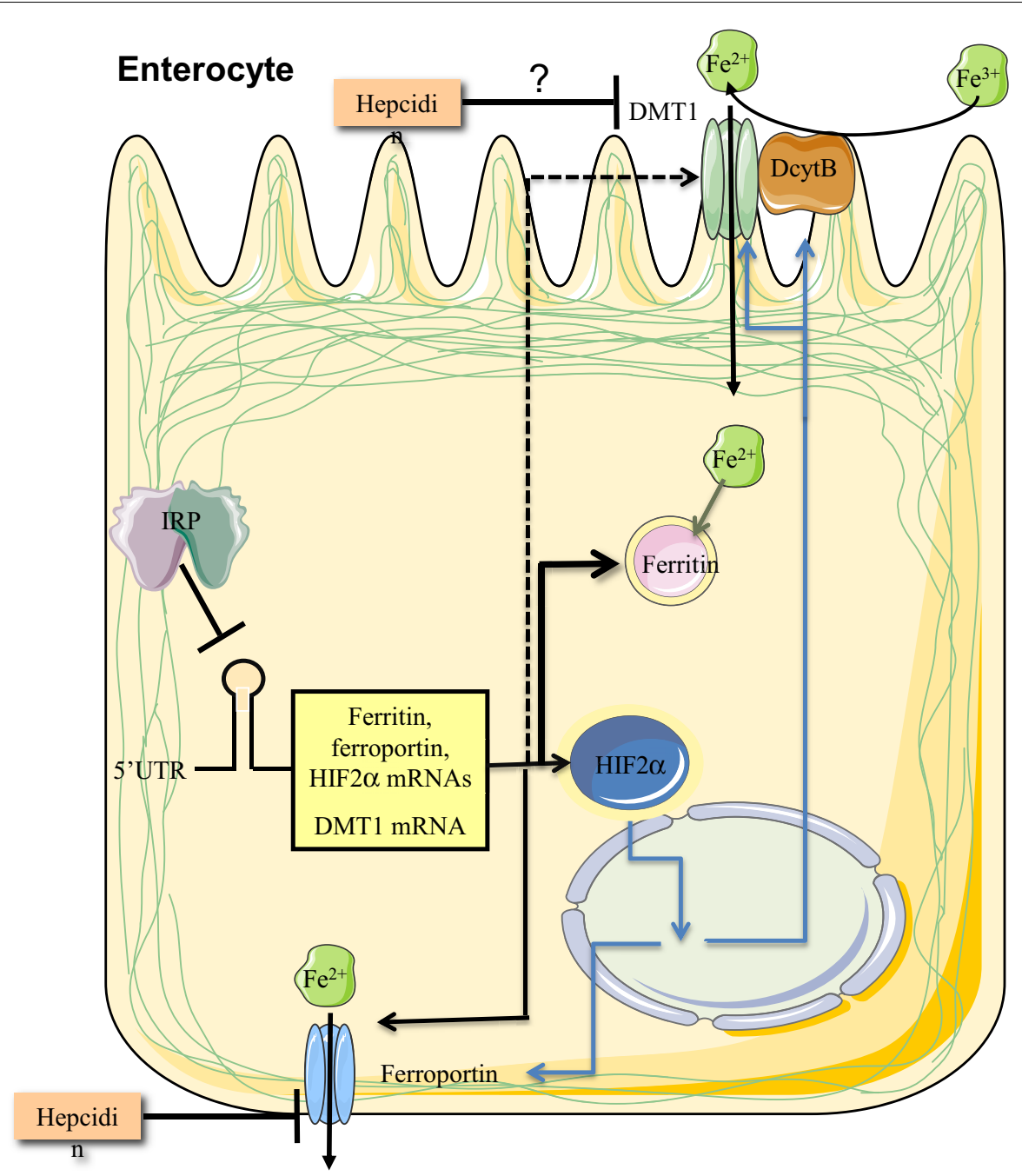

FIGURE 7 | IRPs control dietary iron absorption by limiting ferritin synthesis in duodenal enterocytes. Regulated expression of ferritin is essential to prevent a "mucosal block" following iron intake from the intestinal lumen. In addition, IRPs control the expression of ferroportin and DMT1 mRNAs, the latter only in the period after birth and before weaning.
Finally, IRP1 controls the expression of HIF2 $\alpha$ mRNA, which in turn transcriptionally induces, among other targets, the iron transporters ferroportin and DMT1, and the ferrireductase Dcytb. Ferroportin and possibly also DMT1 are negatively regulated by hepcidin at the level of protein stability. 
regulators of hepcidin, respectively (Ganz, 2013). These stimuli do not operate in a strictly hierarchical manner, and their dominance depends on signal strength (Huang et al., 2009). Hepatic iron overload may be dominant in young animals, and later neutralized by the erythropoietic drive. Nevertheless, 8-10-week-old liver-specific Irp $2^{-/-}$mice, which develop hepatic iron overload without microcytic anemia, exhibit physiological hepcidin expression (Ferring-Appel et al., 2009). This may indicate that Irp2 expression is required for iron-dependent hepcidin induction in mice older than 4-6 weeks, but the underlying mechanism is unclear.

The liver is a major site for excessive iron storage within ferritin, but also the central regulator of systemic iron balance via hepcidin (Meynard et al., 2014). The hepatic iron overload phenotype that was observed in mice with global Irp2 disruption persisted in liver-specific Irp $2^{-/-}$counterparts, which is indicative of a cell autonomous function (Ferring-Appel et al., 2009). Liverspecific disruption of both Irp 1 and Irp 2 resulted in early lethality within 1-2 weeks after birth due to liver failure (Galy et al., 2010). This was associated with mitochondrial iron deficiency, as well as histological and functional defects in this organelle. Thus, the IRE/IRP system is essential for liver function. Along similar lines, unregulated overexpression of endogenous Irp2 in liver-specific $\mathrm{Fbxl5}^{-/-}$mice impaired hepatic and systemic iron homeostasis (Moroishi et al., 2011). The animals developed hepatic iron overload and steatohepatitis, and exhibited inappropriately low hepcidin mRNA expression. Moreover, they succumbed after feeding with an iron-enriched diet due to lethal liver failure.

\section{THE IRE/IRP SYSTEM IN CANCER}

Considering that HIF $2 \alpha$ may function either as a tumor promoter or suppressor (Keith et al., 2012), the regulation of HIF2 $\alpha$ mRNA translation by IRP1 provides a link between the IRE/IRP system and cancer biology. Other links were previously provided by tumor xenograft experiments. Thus, overexpression of IRP1 or a constitutive IRP1 mutant in human H1299 lung cancer cells impaired tumor xenograft growth in nude mice (Chen et al., 2007). Contrary, the overexpression of IRP2 elicited the opposite phenotype, which required the presence of an IRP2-specific 73 amino acids domain (Maffettone et al., 2010). IRE-containing mRNAs were not differentially expressed in IRP1or IRP2-overexpressing xenografts, which exhibited distinct gene expression profiles (Maffettone et al., 2010). These data raise the possibility for a role of IRPs in modulating cancer growth independently of their IRE-binding activities, which remains to be further explored. Nevertheless, IRP2 was recently shown to be overexpressed in breast cancer cells and to promote tumor growth by modulating iron metabolism (Wang et al., 2014). This finding is consistent with reprogramming of iron metabolism in cancer cells (Torti and Torti, 2013). Notably, in earlier experiments IRP2 was reported to be transcriptionally induced by the proto-oncogene c-myc and to promote cell transformation by suppressing ferritin and by regulating cellular iron availability (Wu et al., 1999). On the other hand, the tumor suppressor p53 upregulated ferritin by reducing IRP activities (Zhang et al., 2008). Development of cancer models with $\operatorname{Irp} 1^{-/-}$and Irp $2^{-/-}$ mice is expected to better define the roles of IRPs in cancer and to elucidate the molecular basis underlying the association of IRP2 (IREB2) genomic locus with susceptibility to lung cancer (Hansen et al., 2010; Cho et al., 2012; Fehringer et al., 2012).

\section{CONCLUSIONS}

The discovery of the IRE/IRP regulatory system provided a framework to understand the coordinate regulation of cellular iron uptake via TfR1, and storage within ferritin. Misregulation of Lferritin expression due to "loss of function" mutations in the IRE of its mRNA is clinically relevant and underlies the molecular basis of the hyperferritinemia-caratact syndrome. The expansion of IRE-containing mRNAs raised the possibility that IRPs may control further biochemical pathways. This was firmly established by the analysis of mouse models with global or tissue-specific Irp1 and/or Irp2 deficiency. The animal studies highlighted a key role of the IRE/IRP system in regulation of erythropoiesis, dietary iron absorption, hepatic iron metabolism and body iron homeostasis via crosstalk with the hepcidin/ferroportin axis. These findings may be highly relevant to human medical conditions.

\section{ACKNOWLEDGMENT}

This work was supported by a grant from the Canadian Institutes for Health Research (CIHR; MOP-86514).

\section{REFERENCES}

Aisen, P. (2004). Transferrin receptor 1. Int. J. Biochem. Cell Biol. 36, 2137-2143. doi: 10.1016/j.biocel.2004.02.007

Aisen, P., Enns, C., and Wessling-Resnick, M. (2001). Chemistry and biology of eukaryotic iron metabolism. Int. J. Biochem. Cell Biol. 33, 940-959. doi: 10.1016/S1357-2725(01)00063-2

Allerson, C. R., Cazzola, M., and Rouault, T. A. (1999). Clinical severity and thermodynamic effects of iron-responsive element mutations in hereditary hyperferritinemia-cataract syndrome. J. Biol. Chem. 274, 26439-26447. doi: 10.1074/jbc.274.37.26439

Anderson, S. A., Nizzi, C. P., Chang, Y. I., Deck, K. M., Schmidt, P. J., Galy, B., et al. (2013). The IRP1-HIF-2alpha axis coordinates iron and oxygen sensing with erythropoiesis and iron absorption. Cell Metab. 17, 282-290. doi: 10.1016/j.cmet.2013.01.007

Ang, S. O., Chen, H., Hirota, K., Gordeuk, V. R., Jelinek, J., Guan, Y., et al. (2002). Disruption of oxygen homeostasis underlies congenital Chuvash polycythemia. Nat. Genet. 32, 614-621. doi: 10.1038/ng1019

Arosio, P., Ingrassia, R., and Cavadini, P. (2009). Ferritins: a family of molecules for iron storage, antioxidation and more. Biochim. Biophys. Acta 1790, 589-599. doi: 10.1016/j.bbagen.2008.09.004

Beaumont, C., Leneuve, P., Devaux, I., Scoazec, J.-Y., Berthier, M., Loiseau, M.-N., et al. (1995). Mutation in the iron responsive element of the L ferritin mRNA in a family with dominant hyperferritinaemia and cataract. Nat. Genet. 11, 444-446. doi: 10.1038/ng1295-444

Brasse-Lagnel, C., Karim, Z., Letteron, P., Bekri, S., Bado, A., and Beaumont, C. (2011). Intestinal DMT1 cotransporter is down-regulated by hepcidin via proteasome internalization and degradation. Gastroenterology 140, 1261-1271.e1. doi: 10.1053/j.gastro.2010.12.037

Burn, J., and Chinnery, P. F. (2006). Neuroferritinopathy. Semin. Pediatr. Neurol. 13, 176-181. doi: 10.1016/j.spen.2006.08.006

Camaschella, C., Campanella, A., De Falco, L., Boschetto, L., Merlini, R., Silvestri, L., et al. (2007). The human counterpart of zebrafish shiraz shows sideroblastic-like microcytic anemia and iron overload. Blood 110, 1353-1358. doi: 10.1182/blood-2007-02-072520

Canonne-Hergaux, F., Gruenheid, S., Ponka, P., and Gros, P. (1999). Cellular and subcellular localization of the Nramp2 iron transporter in the intestinal brush border and regulation by dietary iron. Blood 93, 4406-4417.

Casarrubea, D., Viatte, L., Hallas, T., Vasanthakumar, A., Eisenstein, R. S., Schumann, K., et al. (2013). Abnormal body iron distribution and erythropoiesis in a novel mouse model with inducible gain of iron regulatory 
protein (IRP)-1 function. J. Mol. Med. 91, 871-881. doi: 10.1007/s00109-0131008-2

Casey, J. L., Hentze, M. W., Koeller, D. M., Caughman, S. W., Rouault, T. A., Klausner, R. D., et al. (1988). Iron-responsive elements: regulatory RNA sequences that control mRNA levels and translation. Science 240, 924-928. doi: $10.1126 /$ science. 2452485

Casey, J. L., Koeller, D. M., Ramin, V. C., Klausner, R. D., and Harford, J. B. (1989). Iron regulation of transferrin receptor mRNA levels requires iron-responsive elements and a rapid turnover determinant in the $3^{\prime}$ untranslated region of the mRNA. EMBO J. 8, 3693-3699.

Cavill, I. (2002). Erythropoiesis and iron. Best Pract. Res. Clin. Haematol. 15, 399-409. doi: 10.1016/S1521-6926(02)90004-6

Cazzola, M., Bergamaschi, G., Tonon, L., Arbustini, E., Grasso, M., Vercesi, E., et al. (1997). Hereditary hyperferritinemia-cataract syndrome: relationship between phenotypes and specific mutations in the iron-responsive element of ferritin light-chain mRNA. Blood 90, 814-821.

Chappell, S. L., Daly, L., Lotya, J., Alsaegh, A., Guetta-Baranes, T., Roca, J., et al. (2011). The role of IREB2 and transforming growth factor beta-1 genetic variants in COPD: a replication case-control study. BMC Med. Genet. 12:24. doi: 10.1186/1471-2350-12-24

Chen, G., Fillebeen, C., Wang, J., and Pantopoulos, K. (2007). Overexpression of iron regulatory protein 1 suppresses growth of tumor xenografts. Carcinogenesis 28, 785-791. doi: 10.1093/carcin/bgl210

Cho, H. H., Cahill, C. M., Vanderburg, C. R., Scherzer, C. R., Wang, B., Huang, X., et al. (2010). Selective translational control of the Alzheimer amyloid precursor protein transcript by iron regulatory protein-1. J. Biol. Chem. 285, 31217-31232. doi: 10.1074/jbc.M110.149161

Cho, M. H., Castaldi, P. J., Wan, E. S., Siedlinski, M., Hersh, C. P., Demeo, D. L., et al. (2012). A genome-wide association study of COPD identifies a susceptibility locus on chromosome 19q13. Hum. Mol. Genet. 21, 947-957. doi: $10.1093 / \mathrm{hmg} / \mathrm{ddr} 524$

Chollangi, S., Thompson, J. W., Ruiz, J. C., Gardner, K. H., and Bruick, R. K. (2012). Hemerythrin-like domain within F-box and leucine-rich repeat protein 5 (FBXL5) communicates cellular iron and oxygen availability by distinct mechanisms. J. Biol. Chem. 287, 23710-23717. doi: 10.1074/jbc.M112.360404

Chung, B., Chaston, T., Marks, J., Srai, S. K., and Sharp, P. A. (2009). Hepcidin decreases iron transporter expression in vivo in mouse duodenum and spleen and in vitro in THP-1 macrophages and intestinal Caco-2 cells. J. Nutr. 139, 1457-1462. doi: 10.3945/jn.108.102905

Clarke, S. L., Vasanthakumar, A., Anderson, S. A., Pondarre, C., Koh, C. M., Deck, K. M., et al. (2006). Iron-responsive degradation of iron-regulatory protein 1 does not require the Fe-S cluster. EMBO J. 25, 544-553. doi: 10.1038/sj.emboj.7600954

Coon, K. D., Siegel, A. M., Yee, S. J., Dunckley, T. L., Mueller, C., Nagra, R. M., et al. (2006). Preliminary demonstration of an allelic association of the IREB2 gene with Alzheimer's disease. J. Alzheimers. Dis. 9, 225-233.

Cooperman, S. S., Meyron-Holtz, E. G., Olivierre-Wilson, H., Ghosh, M. C., Mcconnell, J. P., and Rouault, T. A. (2005). Microcytic anemia, erythropoietic protoporphyria and neurodegeneration in mice with targeted deletion of iron regulatory protein 2. Blood 106, 1084-1091. doi: 10.1182/blood-2004$12-4703$

Corradini, E., Meynard, D., Wu, Q., Chen, S., Ventura, P., Pietrangelo, A., et al. (2011). Serum and liver iron differently regulate the bone morphogenetic protein 6 (BMP6)-SMAD signaling pathway in mice. Hepatology 54, 273-284. doi: 10.1002/hep.24359

Daba, A., Koromilas, A. E., and Pantopoulos, K. (2012). Alternative ferritin mRNA translation via internal initiation. RNA 18, 547-556. doi: 10.1261/rna.029322.111

Dandekar, T., and Hentze, M. W. (1995). Finding the hairpin in the haystack: searching for RNA motifs. Trends Genet. 11, 45-50. doi: 10.1016/S01689525(00)88996-9

Darshan, D., Wilkins, S. J., Frazer, D. M., and Anderson, G. J. (2011). Reduced expression of ferroportin-1 mediates hyporesponsiveness of suckling rats to stimuli that reduce iron absorption. Gastroenterology 141, 300-309. doi: 10.1053/j.gastro.2011.04.012

Demeo, D. L., Mariani, T., Bhattacharya, S., Srisuma, S., Lange, C., Litonjua, A., et al. (2009). Integration of genomic and genetic approaches implicates IREB2 as a COPD susceptibility gene. Am. J. Hum. Genet. 85, 493-502. doi: 10.1016/j.ajhg.2009.09.004
Drapier, J. C., Hirling, H., Wietzerbin, J., Kaldy, P., and Kühn, L. C. (1993). Biosynthesis of nitric oxide activates iron regulatory factor in macrophages. EMBO J. 12, 3643-3649.

Dupuy, J., Volbeda, A., Carpentier, P., Darnault, C., Moulis, J. M., and FontecillaCamps, J. C. (2006). Crystal structure of human iron regulatory protein 1 as cytosolic aconitase. Structure 14, 129-139. doi: 10.1016/j.str.2005.09.009

Faucheux, B. A., Martin, M. E., Beaumont, C., Hunot, S., Hauw, J. J., Agid, Y., et al. (2002). Lack of up-regulation of ferritin is associated with sustained iron regulatory protein-1 binding activity in the substantia nigra of patients with Parkinson's disease. J. Neurochem. 83, 320-330. doi: 10.1046/j.14714159.2002.01118.x

Fehringer, G., Liu, G., Pintilie, M., Sykes, J., Cheng, D., Liu, N., et al. (2012). Association of the $15 q 25$ and 5p15 lung cancer susceptibility regions with gene expression in lung tumor tissue. Cancer Epidemiol. Biomarkers Prev. 21, 1097-1104. doi: 10.1158/1055-9965.EPI-11-1123-T

Ferring-Appel, D., Hentze, M. W., and Galy, B. (2009). Cell-autonomous and systemic context-dependent functions of iron regulatory protein 2 in mammalian iron metabolism. Blood 113, 679-687. doi: 10.1182/blood-2008-05-155093

Finch, C. (1994). Regulators of iron balance in humans. Blood 84, 1697-1702.

Galy, B., Ferring-Appel, D., Becker, C., Gretz, N., Grone, H. J., Schumann, K., et al. (2013). Iron regulatory proteins control a mucosal block to intestinal iron absorption. Cell Rep. 3, 844-857. doi: 10.1016/j.celrep.2013.02.026

Galy, B., Ferring-Appel, D., Kaden, S., Grone, H. J., and Hentze, M. W. (2008). Iron regulatory proteins are essential for intestinal function and control key iron absorption molecules in the duodenum. Cell Metab. 7, 79-85. doi: 10.1016/j.cmet.2007.10.006

Galy, B., Ferring-Appel, D., Sauer, S. W., Kaden, S., Lyoumi, S., Puy, H., et al. (2010). Iron regulatory proteins secure mitochondrial iron sufficiency and function. Cell Metab. 12, 194-201. doi: 10.1016/j.cmet.2010.06.007

Galy, B., Ferring, D., Benesova, M., Benes, V., and Hentze, M. W. (2004). Targeted mutagenesis of the murine IRPI and IRP2 genes reveals context-dependent RNA processing differences in vivo. RNA 10, 1019-1025. doi: 10.1261/rna.7220704

Galy, B., Ferring, D., and Hentze, M. W. (2005a). Generation of conditional alleles of the murine iron regulatory protein (IRP)-1 and -2 genes. Genesis 43, 181-188. doi: 10.1002/gene.20169

Galy, B., Ferring, D., Minana, B., Bell, O., Janser, H. G., Muckenthaler, M., et al. (2005b). Altered body iron distribution and microcytosis in mice deficient for iron regulatory protein 2 (IRP2). Blood 106, 2580-2589. doi: 10.1182/blood2005-04-1365

Galy, B., Hölter, S. M., Klopstock, T., Ferring, D., Becker, L., Kaden, S., et al. (2006). Iron homeostasis in the brain: complete iron regulatory protein 2 deficiency without symptomatic neurodegeneration in the mouse. Nat. Genet. 38, 967-969. doi: 10.1038/ng0906-967

Ganz, T. (2013). Systemic iron homeostasis. Physiol. Rev. 93, 1721-1741. doi: 10.1152/physrev.00008.2013

Ghosh, M. C., Ollivierre-Wilson, H., Cooperman, S., and Rouault, T. A. (2006). Reply to "Iron homeostasis in the brain: complete iron regulatory protein 2 deficiency without symptomatic neurodegeneration in the mouse". Nat. Genet. 38, 969-970. doi: 10.1038/ng0906-969

Ghosh, M. C., Tong, W. H., Zhang, D., Ollivierre-Wilson, H., Singh, A., Krishna, M. C., et al. (2008). Tempol-mediated activation of latent iron regulatory protein activity prevents symptoms of neurodegenerative disease in IRP2 knockout mice. Proc. Natl. Acad. Sci. U.S.A. 105, 12028-12033. doi: 10.1073/pnas.0805361105

Ghosh, M. C., Zhang, D. L., Jeong, S. Y., Kovtunovych, G., Ollivierre-Wilson, H., Noguchi, A., et al. (2013). Deletion of iron regulatory protein 1 causes polycythemia and pulmonary hypertension in mice through translational derepression of HIF2alpha. Cell Metab. 17, 271-281. doi: 10.1016/j.cmet.2012.12.016

Gkouvatsos, K., Papanikolaou, G., and Pantopoulos, K. (2012). Regulation of iron transport and the role of transferrin. Biochim. Biophys. Acta 1820, 188-202. doi: 10.1016/j.bbagen.2011.10.013

Gunshin, H., Allerson, C. R., Polycarpou-Schwarz, M., Rofts, A., Rogers, J. T., Kishi, F., et al. (2001). Iron-dependent regulation of the divalent metal ion transporter. FEBS Lett. 509, 309-316. doi: 10.1016/S0014-5793(01)03189-1

Gunshin, H., Mackenzie, B., Berger, U. V., Gunshin, Y., Romero, M. F., Boron, W. F., et al. (1997). Cloning and characterization of a mammalian protein-coupled metal-ion transporter. Nature 388, 482-488. doi: 10.1038/41343

Haile, D. J., Rouault, T. A., Harford, J. B., Kennedy, M. C., Blondin, G. A., Beinert, H., et al. (1992). Cellular regulation of the iron-responsive element 
binding protein: disassembly of the cubane iron-sulfur cluster results in highaffinity RNA binding. Proc. Natl. Acad. Sci. U.S.A. 89, 11735-11739. doi: 10.1073/pnas.89.24.11735

Hansen, H. M., Xiao, Y., Rice, T., Bracci, P. M., Wrensch, M. R., Sison, J. D., et al. (2010). Fine mapping of chromosome 15q25.1 lung cancer susceptibility in African-Americans. Hum. Mol. Genet. 19, 3652-3661. doi: $10.1093 / \mathrm{hmg} / \mathrm{ddq} 268$

Hausmann, A., Lee, J., and Pantopoulos, K. (2011). Redox control of iron regulatory protein 2 stability. FEBS Lett. 585, 687-692. doi: 10.1016/j.febslet.2011. 01.036

Hentze, M. W., Caughman, S. W., Rouault, T. A., Barriocanal, J. G., Dancis, A., Harford, J. B., et al. (1987). Identification of the iron-responsive element for the translational regulation of human ferritin mRNA. Science 238, 1570-1573. doi: $10.1126 /$ science. 3685996

Huang, H., Constante, M., Layoun, A., and Santos, M. M. (2009). Contribution of STAT3 and SMAD4 pathways to the regulation of hepcidin by opposing stimuli. Blood 113, 3593-3599. doi: 10.1182/blood-2008-08-173641

Hubert, N., and Hentze, M. W. (2002). Previously uncharacterized isoforms of divalent metal transporter (DMT)-1: implications for regulation and cellular function. Proc. Natl. Acad. Sci. U.S.A. 99, 12345-12350. doi: 10.1073/pnas. 192423399

Jeong, S. Y., Crooks, D. R., Wilson-Ollivierre, H., Ghosh, M. C., Sougrat, R., Lee, J., et al. (2011). Iron insufficiency compromises motor neurons and their mitochondrial function in Irp2-null mice. PLoS ONE 6:e25404. doi: 10.1371/journal.pone.0025404

Joshi, R., Morán, E., and Sanchez, M. (2012). "Cellular iron metabolism. The IRP/IRE regulatory network," in Iron Metabolism, ed S. Arora (Rijeka: InTech), 25-58.

Kallianpur, A. R., Jia, P., Ellis, R. J., Zhao, Z., Bloss, C., Wen, W., et al. (2014). Genetic variation in iron metabolism is associated with neuropathic pain and pain severity in HIV-infected patients on antiretroviral therapy. PLoS ONE. (in press).

Kapitsinou, P. P., Liu, Q., Unger, T. L., Rha, J., Davidoff, O., Keith, B., et al. (2010). Hepatic HIF-2 regulates erythropoietic responses to hypoxia in renal anemia. Blood 116, 3039-3048. doi: 10.1182/blood-2010-02270322

Kato, J., Fujikawa, K., Kanda, M., Fukuda, N., Sasaki, K., Takayama, T., et al. (2001). A mutation, in the iron-responsive element of $\mathrm{H}$ ferritin mRNA, causing autosomal dominant iron overload. Am. J. Hum. Genet. 69, 191-197. doi: $10.1086 / 321261$

Keith, B., Johnson, R. S., and Simon, M. C. (2012). HIF1alpha and HIF2alpha: sibling rivalry in hypoxic tumour growth and progression. Nat. Rev. Cancer 12, 9-22. doi: $10.1038 / \mathrm{nrc} 3183$

Koury, M. J., and Bondurant, M. C. (1990). Erythropoietin retards DNA breakdown and prevents programmed death in erythroid progenitor cells. Science 248, 378-381. doi: 10.1126/science.2326648

LaVaute, T., Smith, S., Cooperman, S., Iwai, K., Land, W., Meyron-Holtz, E., et al. (2001). Targeted deletion of the gene encoding iron regulatory protein-2 causes misregulation of iron metabolism and neurodegenerative disease in mice. Nat. Genet. 27, 209-214. doi: 10.1038/84859

Levi, S., and Arosio, P. (2004). Mitochondrial ferritin. Int. J. Biochem. Cell Biol. 36 , 1887-1889. doi: 10.1016/j.biocel.2003.10.020

Levi, S., Girelli, D., Perrone, F., Pasti, M., Beaumont, C., Corrocher, R., et al. (1998). Analysis of ferritins in lymphoblastoid cell lines and in the lens of subjects with hereditary hyperferritinemia-cataract syndrome. Blood 91, 4180-4187.

Liu, Q., Davidoff, O., Niss, K., and Haase, V. H. (2012). Hypoxia-inducible factor regulates hepcidin via erythropoietin-induced erythropoiesis. J. Clin. Invest. 122, 4635-4644. doi: 10.1172/JCI63924

Lobmayr, L., Brooks, D. G., and Wilson, R. B. (2005). Increased IRP1 activity in Friedreich ataxia. Gene 354, 157-161. doi: 10.1016/j.gene.2005.04.040

Luscieti, S., Tolle, G., Aranda, J., Campos, C. B., Risse, F., Moran, E., et al. (2013). Novel mutations in the ferritin-L iron-responsive element that only mildly impair IRP binding cause hereditary hyperferritinaemia cataract syndrome. Orphanet J. Rare Dis. 8:30. doi: 10.1186/1750-1172-8-30

Maffettone, C., Chen, G., Drozdov, I., Ouzounis, C., and Pantopoulos, K. (2010). Tumorigenic properties of iron regulatory protein 2 (IRP2) mediated by its specific 73-amino acids insert. PLoS ONE 5:e10163. doi: 10.1371/journal.pone. 0010163
Mastrogiannaki, M., Matak, P., Keith, B., Simon, M. C., Vaulont, S., and Peyssonnaux, C. (2009). HIF-2alpha, but not HIF-1alpha, promotes iron absorption in mice. J. Clin. Invest. 119, 1159-1166. doi: 10.1172/JCI38499

Mastrogiannaki, M., Matak, P., Mathieu, J. R., Delga, S., Mayeux, P., Vaulont, S., et al. (2012). Hepatic hypoxia-inducible factor-2 down-regulates hepcidin expression in mice through an erythropoietin-mediated increase in erythropoiesis. Haematologica 97, 827-834. doi: 10.3324/haematol.2011.056119

Mastrogiannaki, M., Matak, P., and Peyssonnaux, C. (2013). The gut in iron homeostasis: role of HIF-2 under normal and pathological conditions. Blood 122, 885-892. doi: 10.1182/blood-2012-11-427765

McKie, A. T., Marciani, P., Rolfs, A., Brennan, K., Wehr, K., Barrow, D., et al. (2000). A novel duodenal iron-regulated transporter IREG1, implicated in the basolateral transfer of iron to the circulation. Mol. Cell 5, 299-309. doi: 10.1016/S1097-2765(00)80425-6

Meynard, D., Babitt, J. L., and Lin, H. Y. (2014). The liver: conductor of systemic iron balance. Blood 123, 168-176. doi: 10.1182/blood-2013-06-427757

Meyron-Holtz, E. G., Ghosh, M. C., Iwai, K., LaVaute, T., Brazzolotto, X., Berger, U. V., et al. (2004a). Genetic ablations of iron regulatory proteins 1 and 2 reveal why iron regulatory protein 2 dominates iron homeostasis. EMBO J. 23, 386-395. doi: 10.1038/sj.emboj.7600041

Meyron-Holtz, E. G., Ghosh, M. C., and Rouault, T. A. (2004b). Mammalian tissue oxygen levels modulate iron-regulatory protein activities in vivo. Science 306, 2087-2090. doi: 10.1126/science.1103786

Moroishi, T., Nishiyama, M., Takeda, Y., Iwai, K., and Nakayama, K. I. (2011). The FBXL5-IRP2 axis is integral to control of iron metabolism in vivo. Cell Metab. 14, 339-351. doi: 10.1016/j.cmet.2011.07.011

Müllner, E. W., and Kühn, L. C. (1988). A stem-loop in the $3^{\prime}$ untranslated region mediates iron-dependent regulation of transferrin receptor mRNA stability in the cytoplasm. Cell 53, 815-825. doi: 10.1016/0092-8674(88)90098-0

Nemeth, E., Tuttle, M. S., Powelson, J., Vaughn, M. B., Donovan, A., Ward, D. M., et al. (2004). Hepcidin regulates cellular iron efflux by binding to ferroportin and inducing its internalization. Science 306, 2090-2093. doi: 10.1126/science. 1104742

Pantopoulos, K., and Hentze, M. W. (1995). Rapid responses to oxidative stress mediated by iron regulatory protein. EMBO J. 14, 2917-2924.

Papanikolaou, G., and Pantopoulos, K. (2005). Iron metabolism and toxicity. Toxicol. Appl. Pharmacol. 202, 199-211. doi: 10.1016/j.taap.2004.06.021

Percy, M. J., Furlow, P. W., Lucas, G. S., Li, X., Lappin, T. R., Mcmullin, M. F., et al. (2008). A gain-of-function mutation in the HIF2A gene in familial erythrocytosis. N. Engl. J. Med. 358, 162-168. doi: 10.1056/NEJMoa073123

Percy, M. J., Zhao, Q., Flores, A., Harrison, C., Lappin, T. R., Maxwell, P. H., et al. (2006). A family with erythrocytosis establishes a role for prolyl hydroxylase domain protein 2 in oxygen homeostasis. Proc. Natl. Acad. Sci. U.S.A. 103, 654-659. doi: 10.1073/pnas.0508423103

Piccinelli, P., and Samuelsson, T. (2007). Evolution of the iron-responsive element. RNA 13, 952-966. doi: 10.1261/rna.464807

Ponka, P. (1997). Tissue-specific regulation of iron metabolism and heme synthesis: distinct control mechanisms in erythroid cells. Blood 89, 1-25.

Ramos, E., Kautz, L., Rodriguez, R., Hansen, M., Gabayan, V., Ginzburg, Y., et al (2011). Evidence for distinct pathways of hepcidin regulation by acute and chronic iron loading in mice. Hepatology 53, 1333-1341. doi: 10.1002/hep.24178

Rankin, E. B., Biju, M. P., Liu, Q., Unger, T. L., Rha, J., Johnson, R. S., et al. (2007), Hypoxia-inducible factor-2 (HIF-2) regulates hepatic erythropoietin in vivo. J. Clin. Invest. 117, 1068-1077. doi: 10.1172/JCI30117

Roetto, A., Bosio, S., Gramaglia, E., Barilaro, M. R., Zecchina, G., and Camaschella, C. (2002). Pathogenesis of hyperferritinemia cataract syndrome. Blood Cells Mol. Dis. 29, 532-535. doi: 10.1006/bcmd.2002.0590

Rouault, T. A. (2006). The role of iron regulatory proteins in mammalian iron homeostasis and disease. Nat. Chem. Biol. 2, 406-414. doi: 10.1038/nchembio807

Ruiz, J. C., Walker, S. D., Anderson, S. A., Eisenstein, R. S., and Bruick, R. K. (2013). F-box and leucine-rich repeat protein 5 (FBXL5) is required for maintenance of cellular and systemic iron homeostasis. J. Biol. Chem. 288, 552-560. doi: 10.1074/jbc.M112.426171

Salahudeen, A. A., Thompson, J. W., Ruiz, J. C., Ma, H. W., Kinch, L. N., Li, Q., et al. (2009). An E3 ligase possessing an iron-responsive hemerythrin domain is a regulator of iron homeostasis. Science 326, 722-726. doi: 10.1126/science.1176326

Sanchez, M., Galy, B., Dandekar, T., Bengert, P., Vainshtein, Y., Stolte, J., et al. (2006). Iron regulation and the cell cycle: identification of an iron-responsive 
element in the $3^{\prime}$-untranslated region of human cell division cycle $14 \mathrm{~A}$ mRNA by a refined microarray-based screening strategy. J. Biol. Chem. 281, 22865-22874. doi: 10.1074/jbc.M603876200

Sanchez, M., Galy, B., Muckenthaler, M. U., and Hentze, M. W. (2007). Ironregulatory proteins limit hypoxia-inducible factor-2alpha expression in iron deficiency. Nat. Struct. Mol. Biol. 14, 420-426. doi: 10.1038/nsmb1222

Sanchez, M., Galy, B., Schwanhaeusser, B., Blake, J., Bahr-Ivacevic, T., Benes, V., et al. (2011). Iron regulatory protein-1 and -2: transcriptome-wide definition of binding mRNAs and shaping of the cellular proteome by iron regulatory proteins. Blood 118, e168-e179. doi: 10.1182/blood-2011-04-343541

Schofield, C. J., and Ratcliffe, P. J. (2004). Oxygen sensing by HIF hydroxylases. Nat. Rev. Mol. Cell Biol. 5, 343-354. doi: 10.1038/nrm1366

Schranzhofer, M., Schifrer, M., Cabrera, J. A., Kopp, S., Chiba, P., Beug, H., et al. (2006). Remodeling the regulation of iron metabolism during erythroid differentiation to ensure efficient heme biosynthesis. Blood 107, 4159-4167. doi: 10.1182/blood-2005-05-1809

Sebastiani, G., and Pantopoulos, K. (2011). Disorders associated with systemic or local iron overload: from pathophysiology to clinical practice. Metallomics 3, 971-986. doi: 10.1039/c1mt00082a

Shah, Y. M., Matsubara, T., Ito, S., Yim, S. H., and Gonzalez, F. J. (2009). Intestinal hypoxia-inducible transcription factors are essential for iron absorption following iron deficiency. Cell Metab. 9, 152-164. doi: 10.1016/j.cmet.2008.12.012

Shah, Y. M., and Xie, L. (2014). Hypoxia-inducible factors link iron homeostasis and erythropoiesis. Gastroenterology 146, 630-642. doi: 10.1053/j.gastro.2013.12.031

Smith, S. R., Cooperman, S., LaVaute, T., Tresser, N., Ghosh, M., Meyron-Holtz, E., et al. (2004). Severity of neurodegeneration correlates with compromise of iron metabolism in mice with iron regulatory protein deficiencies. Ann. N.Y. Acad. Sci. 1012, 65-83. doi: 10.1196/annals.1306.006

Smith, S. R., Ghosh, M. C., Ollivierre-Wilson, H., Hang Tong, W., and Rouault, T. A. (2006). Complete loss of iron regulatory proteins 1 and 2 prevents viability of murine zygotes beyond the blastocyst stage of embryonic development. Blood Cells Mol. Dis. 36, 283-287. doi: 10.1016/j.bcmd.2005.12.006

Synowiec, E., Pogorzelska, M., Blasiak, J., Szaflik, J., and Szaflik, J. P. (2012). Genetic polymorphism of the iron-regulatory protein-1 and -2 genes in age-related macular degeneration. Mol. Biol. Rep. 39, 7077-7087. doi: 10.1007/s11033-0121539-6

Taylor, M., Qu, A., Anderson, E. R., Matsubara, T., Martin, A., Gonzalez, F. J., et al. (2011). Hypoxia-inducible factor-2alpha mediates the adaptive increase of intestinal ferroportin during iron deficiency in mice. Gastroenterology 140, 2044-2055. doi: 10.1053/j.gastro.2011.03.007

Thompson, J. W., Salahudeen, A. A., Chollangi, S., Ruiz, J. C., Brautigam, C. A., Makris, T. M., et al. (2012). Structural and molecular characterization of ironsensing hemerythrin-like domain within F-box and leucine-rich repeat protein 5 (FBXL5). J. Biol. Chem. 287, 7357-7365. doi: 10.1074/jbc.M111.308684

Torti, S. V., and Torti, F. M. (2013). Iron and cancer: more ore to be mined. Nat. Rev. Cancer 13, 342-355. doi: 10.1038/nrc3495

Vanoaica, L., Darshan, D., Richman, L., Schumann, K., and Kuhn, L. C. (2010). Intestinal ferritin $\mathrm{h}$ is required for an accurate control of iron absorption. Cell Metab. 12, 273-282. doi: 10.1016/j.cmet.2010.08.003

Vashisht, A. A., Zumbrennen, K. B., Huang, X., Powers, D. N., Durazo, A., Sun, D., et al. (2009). Control of iron homeostasis by an iron-regulated ubiquitin ligase. Science 326, 718-721. doi: 10.1126/science.1176333

Viatte, L., Grone, H. J., Hentze, M. W., and Galy, B. (2009). In vivo role(s) of the iron regulatory proteins (IRP) 1 and 2 in aseptic local inflammation. J. Mol. Med. 87, 913-921. doi: 10.1007/s00109-009-0494-8

Waheed, A., Parkkila, S., Saarnio, J., Fleming, R. E., Zhou, X. Y., Tomatsu, S., et al. (1999). Association of HFE protein with transferrin receptor in crypt enterocytes of human duodenum. Proc. Natl. Acad. Sci. U.S.A. 96, 1579-1584. doi: 10.1073/pnas.96.4.1579

Walden, W. E., Selezneva, A. I., Dupuy, J., Volbeda, A., Fontecilla-Camps, J. C., Theil, E. C., et al. (2006). Structure of dual function iron regulatory protein 1 complexed with ferritin IRE-RNA. Science 314, 1903-1908. doi: 10.1126/science. 1133116

Wang, J., Chen, G., and Pantopoulos, K. (2005). Nitric oxide inhibits the degradation of IRP2. Mol. Cell. Biol. 25, 1347-1353. doi: 10.1128/MCB.25.4.13471353.2005

Wang, J., Fillebeen, C., Chen, G., Biederbick, A., Lill, R., and Pantopoulos, K. (2007). Iron-dependent degradation of apo-IRP1 by the ubiquitin-proteasome pathway. Mol. Cell. Biol. 27, 2423-2430. doi: 10.1128/MCB.01111-06
Wang, J., and Pantopoulos, K. (2002). Conditional de-repression of ferritin synthesis in cells expressing a constitutive IRP1 mutant. Mol. Cell. Biol. 22, 4638-4651. doi: 10.1128/MCB.22.13.4638-4651.2002

Wang, J., and Pantopoulos, K. (2011). Regulation of cellular iron metabolism. Biochem. J. 434, 365-381. doi: 10.1042/BJ20101825

Wang, W., Deng, Z., Hatcher, H., Miller, L. D., Di, X., Tesfay, L., et al. (2014). IRP2 regulates breast tumor growth. Cancer Res. 74, 497-507. doi: 10.1158/00085472.CAN-13-1224

Weiss, G., and Goodnough, L. T. (2005). Anemia of chronic disease. N. Engl. J. Med. 352, 1011-1023. doi: 10.1056/NEJMra041809

Weiss, G., Goossen, B., Doppler, W., Fuchs, D., Pantopoulos, K., Werner-Felmayer, G., et al. (1993). Translational regulation via iron-responsive elements by the nitric oxide/NO-synthase pathway. EMBO J. 12, 3651-3657.

Wilkinson, N., and Pantopoulos, K. (2013). IRP1 regulates erythropoiesis and systemic iron homeostasis by controlling HIF2alpha mRNA translation. Blood 122, 1658-1668. doi: 10.1182/blood-2013-03-492454

Wingert, R. A., Galloway, J. L., Barut, B., Foott, H., Fraenkel, P., Axe, J. L., et al. (2005). Deficiency of glutaredoxin 5 reveals Fe-S clusters are required for vertebrate haem synthesis. Nature 436, 1035-1039. doi: 10.1038/nature 03887

Wu, K. J., Polack, A., and Dalla-Favera, R. (1999). Coordinated regulation of ironcontrolling genes, H-ferritin and IRP2, by c-MYC. Science 283, 676-679. doi: 10.1126/science.283.5402.676

Yang, X. R., Liang, X., Pfeiffer, R. M., Wheeler, W., Maeder, D., Burdette, L., et al. (2010). Associations of 9p21 variants with cutaneous malignant melanoma, nevi, and pigmentation phenotypes in melanoma-prone families with and without CDKN2A mutations. Fam. Cancer 9, 625-633. doi: 10.1007/s10689010-9356-3

Ye, H., Jeong, S. Y., Ghosh, M. C., Kovtunovych, G., Silvestri, L., Ortillo, D., et al. (2010). Glutaredoxin 5 deficiency causes sideroblastic anemia by specifically impairing heme biosynthesis and depleting cytosolic iron in human erythroblasts. J. Clin. Invest. 120, 1749-1761. doi: 10.1172/JCI40372

Yin, D., Kulhalli, V., and Walker, A. P. (2014). Raised serum ferritin concentration in hereditary hyperferritinemia cataract syndrome is not a marker for iron overload. Hepatology 59, 1204-1206. doi: 10.1002/hep.26681

Zhang, D. L., Hughes, R. M., Ollivierre-Wilson, H., Ghosh, M. C., and Rouault, T. A. (2009). A ferroportin transcript that lacks an iron-responsive element enables duodenal and erythroid precursor cells to evade translational repression. Cell Metab. 9, 461-473. doi: 10.1016/j.cmet.2009.03.006

Zhang, F., Wang, W., Tsuji, Y., Torti, S. V., and Torti, F. M. (2008). Posttranscriptional modulation of iron homeostasis during p53-dependent growth arrest. J. Biol. Chem. 283, 33911-33918. doi: 10.1074/jbc.M806432200

Zhou, H., Yang, J., Li, D., Xiao, J., Wang, B., Wang, L., et al. (2012). Association of IREB2 and CHRNA3/5 polymorphisms with COPD and COPD-related phenotypes in a Chinese Han population. J. Hum. Genet. 57, 738-746. doi: 10.1038/jhg.2012.104

Zimmer, M., Ebert, B. L., Neil, C., Brenner, K., Papaioannou, I., Melas, A., et al. (2008). Small-molecule inhibitors of HIF-2a translation link its 5'UTR iron-responsive element to oxygen sensing. Mol. Cell 32, 838-848. doi: 10.1016/j.molcel.2008.12.004

Zumbrennen-Bullough, K. B., Becker, L., Garrett, L., Hölter, S. M., Calzada-Wack, J., Mossburger, I., et al. (2014). Abnormal brain iron metabolism in Irp2 deficient mice is associated with mild neurological and behavioral impairments. PLoS ONE 9:e98072. doi: 10.1371/journal.pone.0098072

Conflict of Interest Statement: The authors declare that the research was conducted in the absence of any commercial or financial relationships that could be construed as a potential conflict of interest.

Received: 05 May 2014; accepted: 07 July 2014; published online: 28 July 2014. Citation: Wilkinson N and Pantopoulos K (2014) The IRP/IRE system in vivo: insights from mouse models. Front. Pharmacol. 5:176. doi: 10.3389/fphar.2014.00176

This article was submitted to Drug Metabolism and Transport, a section of the journal Frontiers in Pharmacology.

Copyright (C) 2014 Wilkinson and Pantopoulos. This is an open-access article distributed under the terms of the Creative Commons Attribution License (CC BY). The use, distribution or reproduction in other forums is permitted, provided the original author(s) or licensor are credited and that the original publication in this journal is cited, in accordance with accepted academic practice. No use, distribution or reproduction is permitted which does not comply with these terms. 